This document was prepared in conjunction with work accomplished under Contract No. DE-AC09-96SR18500 with the U. S. Department of Energy.

\title{
DISCLAIMER
}

This report was prepared as an account of work sponsored by an agency of the United States Government. Neither the United States Government nor any agency thereof, nor any of their employees, makes any warranty, express or implied, or assumes any legal liability or responsibility for the accuracy, completeness, or usefulness of any information, apparatus, product or process disclosed, or represents that its use would not infringe privately owned rights. Reference herein to any specific commercial product, process or service by trade name, trademark, manufacturer, or otherwise does not necessarily constitute or imply its endorsement, recommendation, or favoring by the United States Government or any agency thereof. The views and opinions of authors expressed herein do not necessarily state or reflect those of the United States Government or any agency thereof.

This report has been reproduced directly from the best available copy.

Available for sale to the public, in paper, from: U.S. Department of Commerce, National Technical Information Service, 5285 Port Royal Road, Springfield, VA 22161, phone: (800) 553-6847, fax: (703) 605-6900

email: orders@ntis.fedworld.gov

online ordering: http://www.ntis.gov/help/index.asp

Available electronically at http://www.osti.gov/bridge

Available for a processing fee to U.S. Department of Energy and its contractors, in paper, from: U.S. Department of Energy, Office of Scientific and Technical Information, P.O. Box 62, Oak Ridge, TN 37831-0062,

phone: (865)576-8401,

fax: (865)576-5728

email: $\underline{\text { reports@ adonis.osti.gov }}$ 
WSRC-TR-2002-00307, REV. 0

Key Words: Cesium,

Waste processing

Retention: Permanent

\section{DEMONSTRATION OF CAUSTIC-SIDE SOLVENT EXTRACTION WITH OPTIMIZED SOLVENT \\ IN THE 2-CM CENTRIFUGAL CONTACTOR APPARATUS \\ USING DISSOLVED SALT CAKE FROM TANK 37H}

M. A. Norato, S. D. Fink, F. F. Fondeur, G. F. Kessinger, R. A. Pierce, and D. D. Walker

August 23, 2002

Westinghouse Savannah River Company

Savannah River Site

Aiken, SC 29808

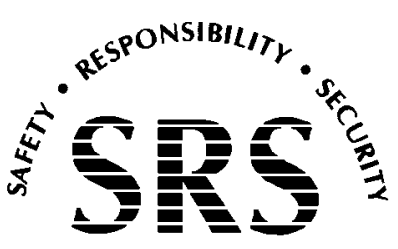

SAVANNAH RIVER SITE

Prepared for the U.S. Department of Energy Under

Contract Number DE-AC09-96SR18500 
WSRC-TR-2002-00307, REV. 0

REVIEWS AND APPROVALS

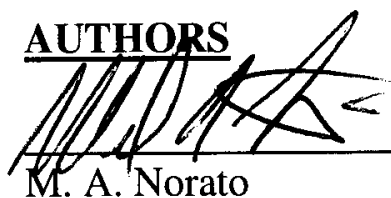

fervuals fmelew

F.F. Fprdeur, W.PTS

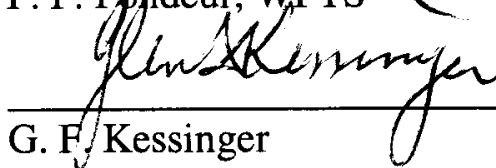

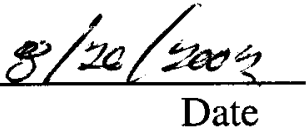

8.26 .02

Qherce

R. A. Pierce

Qarred D. Walker

D. D. Walker, WPTS

$8 / 26 / 02$

$\frac{8 / 26 / 02}{\text { Date }}$

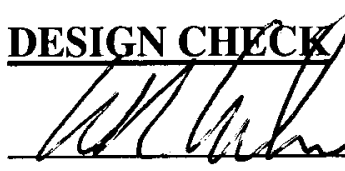

$8 / 26 / 02$

W. R. Wilmarth, WPTS (per Manual E7, Procedure 2.40)

$\frac{8 / 26 / 02}{\text { Date }}$

APPROVALS

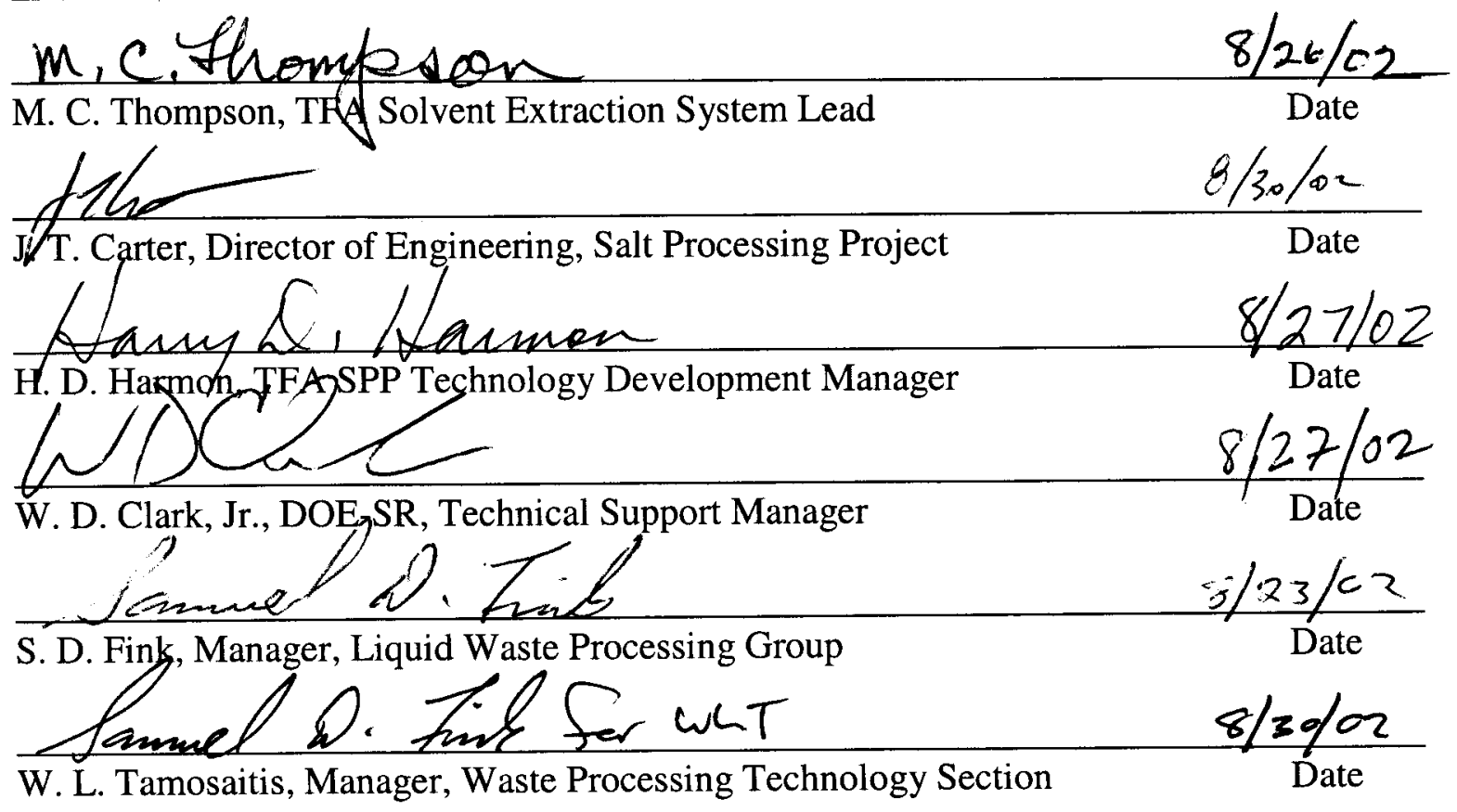




\section{TABLE OF CONTENTS}

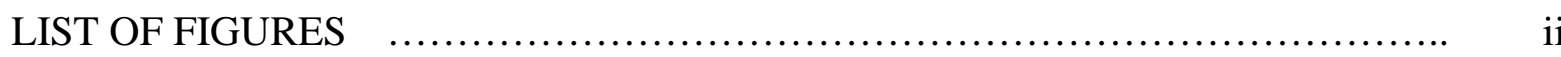

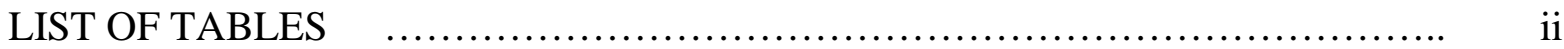

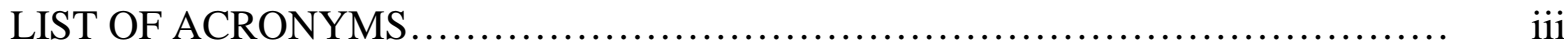

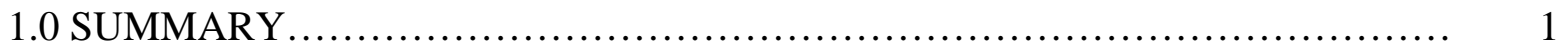

2.0 INTRODUCTION ................................................................ 2

3.0 TANK 37H WASTE TEST REQUIREMENTS .............................. 3

4.0 EXPERIMENTAL....................................................... 4

4.1 Simulated Tank 37H Waste.................................................. 4

4.2 Tank 37H Waste Dilution............................................. 4

4.3 Tank 37H Waste MST Strike and Filtration................................. 5

4.4 Contactor Configuration..................................................... 5

4.4.1 Physical Configuration................................................ 5

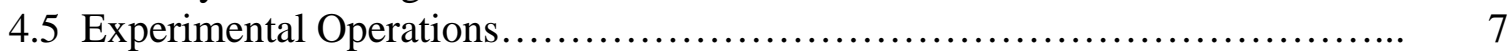

4.6 Sampling and Analysis.................................................... 9

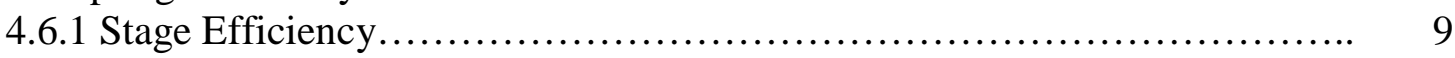

4.6.2 Decontamination and Concentration Factors............................ 10

4.6.3 Solvent Entrainment and Degradation................................ $\quad 10$

4.6.4 Minor Components................................................. 10

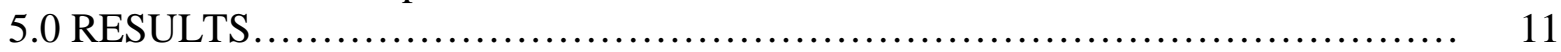

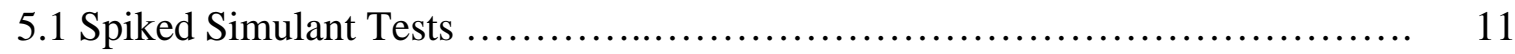

5.1 .1 Hydraulic Performance................................................. 11

5.1.2 Simulant Decontamination........................................... 12

5.2 Tank 37H Waste Contactor Test........................................ 12

5.2.1 Hydraulic Performance........................................... 12

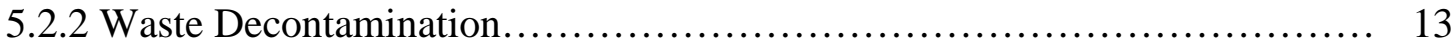

5.2.3 Solvent Decontamination............................................. 14

5.2.4 Concentration Factors............................................. 14

5.2.5 Second Phase Carryover............................................. 16

5.2.6 Solvent Condition and Impurities.................................... 17

5.2.7 Organic Compounds in Aqueous Streams................................ 17

5.2.8 Technetium in Process Streams......................................... 17

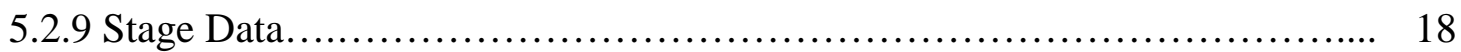

5.2.10 Stage Temperatures................................................ 21

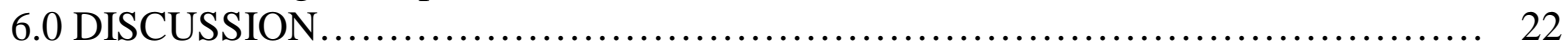

6.1 Tank 37H Waste Composition............................................ 22

6.2 Hydraulic Performance....................................................... 22

6.3 Second Phase Carryover.................................................... 23

6.4 Waste and Solvent Decontamination....................................... 23

6.4.1 Spiked Simulant Testing............................................. 24

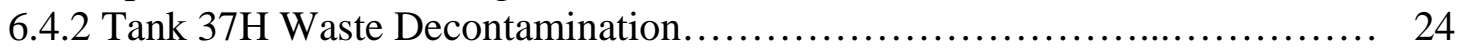

6.4.3 Solvent Decontamination............................................... 24

6.4.4 Concentration Factor.................................................. 25

6.5 Solvent Condition and Impurities........................................ 27

Page $\mathrm{i}$ of iii 
6.6 Technetium in Process Streams............................................. 27

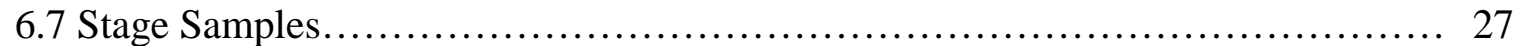

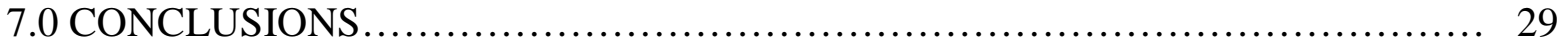

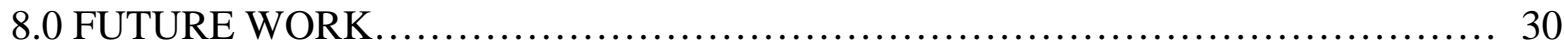

9.0 ACKNOWLEDGEMENTS .................................................. 30

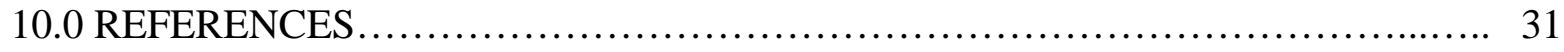

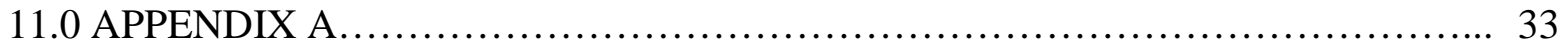

\section{LIST OF FIGURES}

1. Flow diagram.................................................................. 7

2. Equipment layout diagram................................................. 8

3. General contactor configuration........................................... 8

4. Spiked simulant decontamination value ..................................... 12

5. Waste DF value as a function of time........................................... 14

6. Solvent DF values as a function of time...................................... 15

7. CF values as a function of time.............................................. 15

8. Comparison of stage sample data and SASSE calculations......................... 20

9. Comparison of estimated and measured CF values............................... 26

\section{LIST OF TABLES}

I. Composition of Simulated Waste Solution.................................. 4

II. Origin of Tank 37H Waste............................................ 5

III. Composition of Tank 37H Waste....................................... 6

IV. Observed Flow Rates for Spiked Simulant Test............................ 11

V. Observed Flow Rates and O/A Ratios.................................... 13

VI. Second Phase Carryover for Tank 37H Waste Test............................. 16

VII. Solvent Components in Aqueous Process Streams............................. 16

VIII. Solvent Composition and Minor Components............................... 17

IX. Organic Compounds in Aqueous Streams............................... 18

X. Technetium in Process Streams............................................ 18

XI. Stage Sample Cesium Distribution Coefficients............................... 19

XII. Cesium Distribution Coefficients for Tank 37H Waste......................... 20

XIII. Parameter Values Used in SASSE Calculation.............................. 21

XIV. Temperature Ranges for Contactor Sections................................ 21

XV. Combined Minor Phase Carryover Results................................ 23 


\section{LIST OF ACRONYMS}

$\begin{array}{ll}\text { AA } & \text { Atomic Absorption } \\ \text { ADS } & \text { Analytical Development Section } \\ \text { ANL } & \text { Argonne National Laboratory } \\ \text { BOBCalix } & \text { Calix[4]arene-bis-(tert-octylbenzo-crown-6) } \\ \text { BuOH } & n \text {-butanol } \\ \text { CF } & \text { Concentration Factor } \\ \text { CSSX } & \text { Caustic-Side Solvent Extraction } \\ \text { DBP } & \text { dibutyl phosphate } \\ \text { DF } & \text { Decontamination Factor } \\ \text { DOA } & \text { di-n-octylamine } \\ \text { DWPF } & \text { Defense Waste Processing Facility } \\ \text { FMI } & \text { Fluid Metering, Inc. } \\ \text { GC-MS } & \text { Gas Chromatography - Mass Spectrometry } \\ \text { HLW } & \text { High Level Waste } \\ \text { HPLC } & \text { High Performance Liquid Chromatography } \\ \text { IC } & \text { Ion Chromatrography } \\ \text { ICP-ES } & \text { Inductively Coupled Plasma Emission Spectroscopy } \\ \text { ICP-MS } & \text { Inductively Coupled Plasma Mass Spectroscopy } \\ \text { INEEL } & \text { Idaho National Engineering and Environmental Laboratory } \\ \text { MST } & \text { monosodium titanate } \\ \text { O/A } & \text { organic-to-aqueous volume ratio } \\ \text { ORNL } & \text { Oak Ridge National Laboratory } \\ \text { SASSE } & \text { Spreadsheet Algorithm for Stagewise Solvent Extraction } \\ \text { SBP } & \text { 4-sec-butylphenol } \\ \text { SRS } & \text { Savannah River Site } \\ \text { SRTC } & \text { Savannah River Technology Center } \\ \text { SVOA } & \text { Semivolatile Organic Analysis } \\ \text { TMA } & \text { trimethylamine } \\ \text { TOA } & \text { trioctylamine } \\ \text { TBP } & \text { tributyl phosphate } \\ \text { WAC } & \text { Waste Acceptance Criterion } \\ \text { WPTS } & \text { Waste Processing Technology Section } \\ & \end{array}$




\subsection{SUMMARY}

Researchers successfully demonstrated the chemistry of the Caustic-Side Solvent Extraction (CSSX) flow sheet with optimized solvent. This represents the third such process demonstration using actual Savannah River Site (SRS) high level waste (HLW). ${ }^{1-2}$ The present test differed from previous studies in the use of radioactive waste derived from Tank $37 \mathrm{H}$ dissolved salt cake, as opposed to supernate solutions used in previous demonstrations. The test used a 33-stage, 2-cm centrifugal contactor apparatus in a shielded facility at the Savannah River Technology Center (SRTC). The test with Tank $37 \mathrm{H}$ waste processed 44.6 $\mathrm{L}$ of solution in 25.5 hours. A 4-hour trial with simulated Tank $37 \mathrm{H}$ waste preceded the demonstration. Conclusions from this work follow.

- The CSSX process using optimized solvent reduces ${ }^{137} \mathrm{Cs}$ in dissolved salt cake solutions to concentrations below the Saltstone waste acceptance criterion (WAC) of $45 \mathrm{nCi} / \mathrm{g}$.

- Waste decontamination factors (DFs) as high as 3 million resulted during testing.

- The DF for the combined waste accumulated over the first 16 hours at nominal process settings equaled 352,000.

- Personnel then decreased the solvent flow rate and increased waste flow to simulate extreme operating conditions. The measured DF values averaged 28,600 for the remaining 9.5 hours of testing, satisfying the Saltstone WAC.

- Stripping cesium from the solvent and recycling resulted in an average solvent DF of 22,100 during the first 16 hours and 114,000 during the remaining 9.5 hours of the test.

- Testing occurred over 25.5 hours of uninterrupted operation, demonstrating hydraulic stability of the contactor array over a range of process conditions.

- Tests with Tank $37 \mathrm{H}$ waste demonstrated extraction and strip section stage efficiencies of $90 \%$ and $80 \%$, respectively.

- These exceed or equal the process goal of $80 \%$ efficiency.

- Carryover of organic solvent in aqueous streams (and aqueous in organic streams) proved less than $1 \%$ when processing Tank $37 \mathrm{H}$ waste.

- Minor chemical species in the Tank $37 \mathrm{H}$ waste did not affect the ability of the contactors to efficiently separate the solvent and aqueous phases.

- The concentration factor (CF) averaged 13.2 during the first 16 hours of operation with Tank $\mathrm{H}$ waste and 15.8 in the remaining 9.5 hours.

- Uncertainties in process flow rate measurement and control prevented the test from achieving the target $\mathrm{CF}$ of 15 during the initial portion of the test. 
WSRC-TR-2002-00307, REV. 0

\subsection{INTRODUCTION}

A solvent extraction process for removal of cesium from alkaline solutions has been developed utilizing a novel solvent invented at the Oak Ridge National Laboratory (ORNL). ${ }^{3}$ This solvent consists of a calix[4]arene-crown-6 extractant (BOBCalix) dissolved in an inert hydrocarbon matrix (Isopar ${ }^{\circledR}$ L). An alkylphenoxy alcohol modifier added to the solvent enhances the extraction power of the calixarene and prevents the formation of a third phase. An additional additive, trioctylamine (TOA), improves stripping performance and mitigates the effects of any surfactants present in the feed stream. ${ }^{4}$ The solvent extraction process was successfully demonstrated with actual SRS HLW supernate during testing performed at SRTC in FY-2001. ${ }^{1}$ However, the solvent system has recently been optimized to enhance extractant solubility in the diluent and increase suppressor concentration. The results of the optimized solvent performance in tests using the same SRS composite waste supernate as was used FY-2001 are described in another report. ${ }^{2}$

The SRS tank farms store soluble HLW in two forms, supernate and salt cake. Researchers postulate that the separation of the waste into two phases will create differences in composition between the two forms that may affect solvent extraction processing. In particular, it was postulated that liquid waste derived from salt cake would contain higher concentrations of nitrite compared to supernate. Previous testing with actual waste ${ }^{1}$ demonstrated the process chemistry for supernate solution and testing with simulated waste suggested an adverse effect from high nitrite concentrations. ${ }^{5}$ Researchers undertook the present testing to demonstrate that acceptable waste DFs could be achieved with dissolved salt cake waste. Subsequently, ORNL researchers determined an anti-caking surfactant found in some sodium nitrite sources caused the observed adverse stripping effects. ${ }^{5}$

SRS plans for waste dissolution in Tank $37 \mathrm{H}$ and transfer to Tank $30 \mathrm{H}$ proved a timely source of dissolved salt cake for the CSSX demonstration. ${ }^{6}$ Following removal of the supernate solution and addition of water for salt cake dissolution, Waste Management personnel obtained a 38-L sample of solution from Tank 37H. Although the original CSSX test plan specified a minimum of 12 hours of operation, SRTC received sufficient Tank 37H waste to support a 24-hour test. This allowed examination of conditions significantly different from the normal flowsheet values in addition to the nominal values. Researchers tested the effect of lowering the extraction $\mathrm{O} / \mathrm{A}$ ratio from $1 / 3$ to $1 / 4$ by decreasing the solvent flow rate. The resulting data has potential use in evaluating the operational limits of the 2-cm contactor apparatus and options for processing waste faster with lower decontamination factors.

This report summarizes the results of tests at SRTC with radioactively spiked simulated Tank $37 \mathrm{H}$ waste and actual Tank $37 \mathrm{H}$ waste. The 4-hour simulant test demonstrated that stable hydraulic conditions and DFs near the target value of 40,000 when the contactor apparatus operated with the new waste feed and modified solvent. The 25.5-hour actual Tank $37 \mathrm{H}$ waste test demonstrated similar hydraulic stability and higher DFs.

Page 2 of 39 


\subsection{TANK 37H WASTE TEST REQUIREMENTS}

The technical and quality assurance plan ${ }^{7}$ defined the requirements for the Tank $37 \mathrm{H}$ waste test in the 2 -cm centrifugal contactor apparatus. The most important requirements follow.

- Use actual high-level radioactive waste solution derived from Tank $37 \mathrm{H}$ dissolved salt cake.

- Operate the process for at least 12 hours.

- Determine waste DF.

- Determine solvent DF.

- Determine cesium CF in strip raffinate.

- Analyze effluent streams for organic compounds, including radiolytic degradation products.

- Compare test results against the Saltstone waste acceptance criterion $\left(<45 \mathrm{nCi} / \mathrm{g}{ }^{137} \mathrm{Cs}\right)$. 


\subsection{EXPERIMENTAL}

\subsection{SIMULATED TANK 37H WASTE}

The 2-cm contactor test used a simulant of the Tank $37 \mathrm{H}$ waste to demonstrate equipment readiness and performance verification prior to testing with the actual Tank $37 \mathrm{H}$ waste. Table I lists the composition of the simulated Tank $37 \mathrm{H}$ waste. The simulant was initially prepared without cesium. We used a cesium-free solution to fill the contactors and establish fluid flows during startup without contaminating the apparatus with cesium. The cesiumcontaining solution used for equipment verification testing contained non-radioactive cesium (as $\mathrm{CsCl}$ ) at the concentration indicated in Table I. In addition, the solution $(10 \mathrm{~L})$ was spiked with ${ }^{137} \mathrm{Cs}$ using a $125 \mathrm{~mL}$ aliquot of the actual Tank $37 \mathrm{H}$ waste. This provided a ${ }^{137} \mathrm{Cs}$ activity of $\sim 4 \times 10^{7} \mathrm{~d} / \mathrm{m} / \mathrm{mL}$ to verify decontamination and concentration factors. The simulant was prepared from reagent grade chemicals. Following dissolution of the chemicals, the solution aged 24 hours before filtering ( 25 micron nominal pore size, spun polypropylene filter element) and transfer to a clean carboy. The SRTC Analytical Development Section (ADS) verified the major component concentration by routine analyses.

\subsection{TANK 37H WASTE DILUTION}

SRS Waste Management personnel filled a 38-L sampler with liquid radioactive waste from Tank 37H in April 2002, during salt cake dissolution operations. After transporting the sample to SRTC, personnel placed the sample into a shielded facility for processing. Table II summarizes source information for the sample.

TABLE I. Composition of Simulated Waste Solution

\begin{tabular}{|l|l|}
\hline Component & Average (M) \\
\hline $\mathrm{Na}^{+}$ & 6.22 \\
\hline $\mathrm{K}^{+}$ & 0.059 \\
\hline $\mathrm{Cs}^{+}$ & 0.00034 \\
\hline $\mathrm{OH}^{-}$ & 3.85 \\
\hline $\mathrm{NO}_{3}{ }^{-}$ & 0.67 \\
\hline $\mathrm{NO}_{2}{ }^{-}$ & 0.88 \\
\hline $\mathrm{AlO}_{2}^{-}$ & 0.54 \\
\hline $\mathrm{CO}_{3}{ }^{2-}$ & 0.10 \\
\hline
\end{tabular}

\begin{tabular}{|l|l|}
\hline Component & Average (M) \\
\hline $\mathrm{SO}_{4}{ }^{2-}$ & 0.003 \\
\hline $\mathrm{Cl}^{-}$ & 0.009 \\
\hline $\mathrm{F}^{-}$ & 0.005 \\
\hline $\mathrm{PO}_{4}{ }^{3-}$ & 0.020 \\
\hline & \\
\hline & \\
\hline & \\
\hline & \\
\hline
\end{tabular}


TABLE II. Origin of Tank 37H Waste

Source

Date Sampled

Identification Number

Date received at SRTC

Approximate volume (L)

Density ( $g / \mathrm{mL})$

$\mathrm{Na}^{+}$(molarity)
Tank $37 \mathrm{H}$

$4 / 16 / 2002$

HTK-496

$4 / 17 / 02$

37

1.490

$\sim 14$

The sodium ion concentration of the as-received waste solution (density, $1.490 \mathrm{~g} / \mathrm{mL} ; \sim 14 \mathrm{M}$ $\mathrm{Na}^{+}$) exceeded the desired processing concentration of $5.6 \mathrm{M} \mathrm{Na}^{+}$. Personnel transferred a portion of the waste solution $(25.5 \mathrm{~L})$ to an empty tank and diluted it with $1.6 \mathrm{M} \mathrm{NaOH}$ solution $(45 \mathrm{~L})$ simulating the planned operations for the Salt Waste Processing Facility. After dilution, the final sodium ion concentration of $6.22 \mathrm{M}$ was deemed adequately close to the 5.6 $\mathrm{M}$ target. Table III lists the composition of the diluted solution. Researchers measured the solution density by weighing portions in $50-\mathrm{mL}$ volumetric flasks using a balance sensitive to $\pm 1 \mathrm{mg}$. Unfiltered portions $(1 \mathrm{~mL})$ were diluted in 99 grams of water or $0.2 \mathrm{M}$ nitric acid and sent to the ADS for routine analyses. The exact dilution factors were calculated from the density, weight of the nominal 1-mL sample, and weight of the water, assuming ideal mixing of the waste and water. The sodium ion concentration was measured by inductively-coupled plasma emission spectroscopy (ICP-ES).

\subsection{TANK 37H WASTE MST STRIKE AND FILTRATION}

Monosodium titanate (MST) treatment of the diluted Tank $37 \mathrm{H}$ waste removed strontium and actinides. ${ }^{8}$ The waste contacted the MST for 36 hours prior to filtration. Filtration used a Whatman Polycap ${ }^{\mathrm{TM}} 75 \mathrm{TF}$ filter device (0.45 micron Teflon filter element). Personnel stored the filtered solution in a clean, tightly capped carboy for 5 weeks until used in solvent extraction testing. Researchers did not check for solids precipitated during storage before processing the filtered waste solution.

\subsection{CONTACTOR CONFIGURATION}

\subsubsection{Physical Configuration}

The process equipment consisted of a 33-stage, 2-cm annular centrifugal contactor apparatus used in previous actual waste demonstrations at SRTC. Argonne National Laboratory (ANL) personnel designed and fabricated the contactor stages. A previous ${ }^{1}$ report describes details of the apparatus configuration and process flow sheet. Figure 1 shows a process flow diagram displaying flow conditions specific to this test. 
TABLE III. Composition of the Tank 37H Waste*

\begin{tabular}{|c|c|c|c|}
\hline Component & Concentration(M) & Component & Concentration $(\mathrm{mg} / \mathrm{L})$ \\
\hline $\mathrm{Na}^{+}$ & 6.22 & $\overline{\mathrm{Ag}}$ & $<0.6$ \\
\hline $\mathrm{K}^{+}$ & 0.039 & $\mathrm{Ba}$ & 3.8 \\
\hline $\mathrm{Rb}^{+}$ & $<0.00033$ & $\mathrm{Ca}$ & $<0.1$ \\
\hline \multirow{2}{*}{$\mathrm{Cs}^{+}$} & 0.00034 & $\mathrm{Cd}$ & 1.1 \\
\hline & & $\mathrm{Cr}$ & 170 \\
\hline Free $\mathrm{OH}^{-}$ & 3.7 & $\mathrm{Hg}$ & $<12$ \\
\hline $\mathrm{NO}_{3}^{-}$ & 0.73 & $\mathrm{Mg}$ & 9.4 \\
\hline $\mathrm{NO}_{2}^{-}$ & 0.88 & $\mathrm{~Pb}$ & 9.4 \\
\hline $\mathrm{AlO}_{2}^{-}$ & 0.54 & $\mathrm{Sr}$ & $<0.1$ \\
\hline $\mathrm{SO}_{4}^{2-}$ & $<0.006$ & & \\
\hline $\mathrm{CO}_{3}^{2-}$ & $<0.02$ & Radionuclide & $\operatorname{Activity}(\mathrm{d} / \mathrm{m} / \mathrm{mL})^{* *}$ \\
\hline $\mathrm{PO}_{4}^{3-}$ & 0.02 & $\overline{C s-137}$ & $3.2 \times 10^{9}$ \\
\hline $\mathrm{F}^{-}$ & $<0.012$ & Tritium & $6.1 \times 10^{2}$ \\
\hline $\mathrm{Cl}^{-}$ & 0.009 & C-14 & $<2 \times 10^{1}$ \\
\hline Oxalate & $<0.013$ & Тc-99 & $5.5 \times 10^{5}$ \\
\hline Formate & $<0.025$ & $\mathrm{I}-129$ & $<7 \times 10^{1}$ \\
\hline $\begin{array}{l}\text { Density } \\
\text { pH }\end{array}$ & $>_{>} 1.240 \mathrm{~g} / \mathrm{mL}$ & & \\
\hline
\end{tabular}

Circulating cooling water maintained the extraction section temperatures between 21 and $26{ }^{\circ} \mathrm{C}$ in a method similar to that described previously. ${ }^{1}$ In the present study, a manually controlled chiller (NesLab RTE-111) provided cooling water rather than the computer controlled chiller used in earlier testing.

Pumps manufactured by Fluid Metering, Inc. (FMI) fed liquids to the contactors. Rheotherm ${ }^{\circledR}$ flow instruments used in previous test proved unreliable after long-term exposure to radiation in the shielded facility. Therefore, the pumps operated under manual control for the duration of the test instead of using the feedback control routine described previously. ${ }^{1}$ Manual control consisted of calibrating each pump prior to the test, and performing periodic graduated cylinder and stopwatch flow measurements during the test. Manual adjustment of the feed pump speeds occurred as necessary based on the manual flow measurements. The workstation running the Intellution FIX 7.0 process control software served only for pump speed adjustments and data acquisition interface in this test. As in 


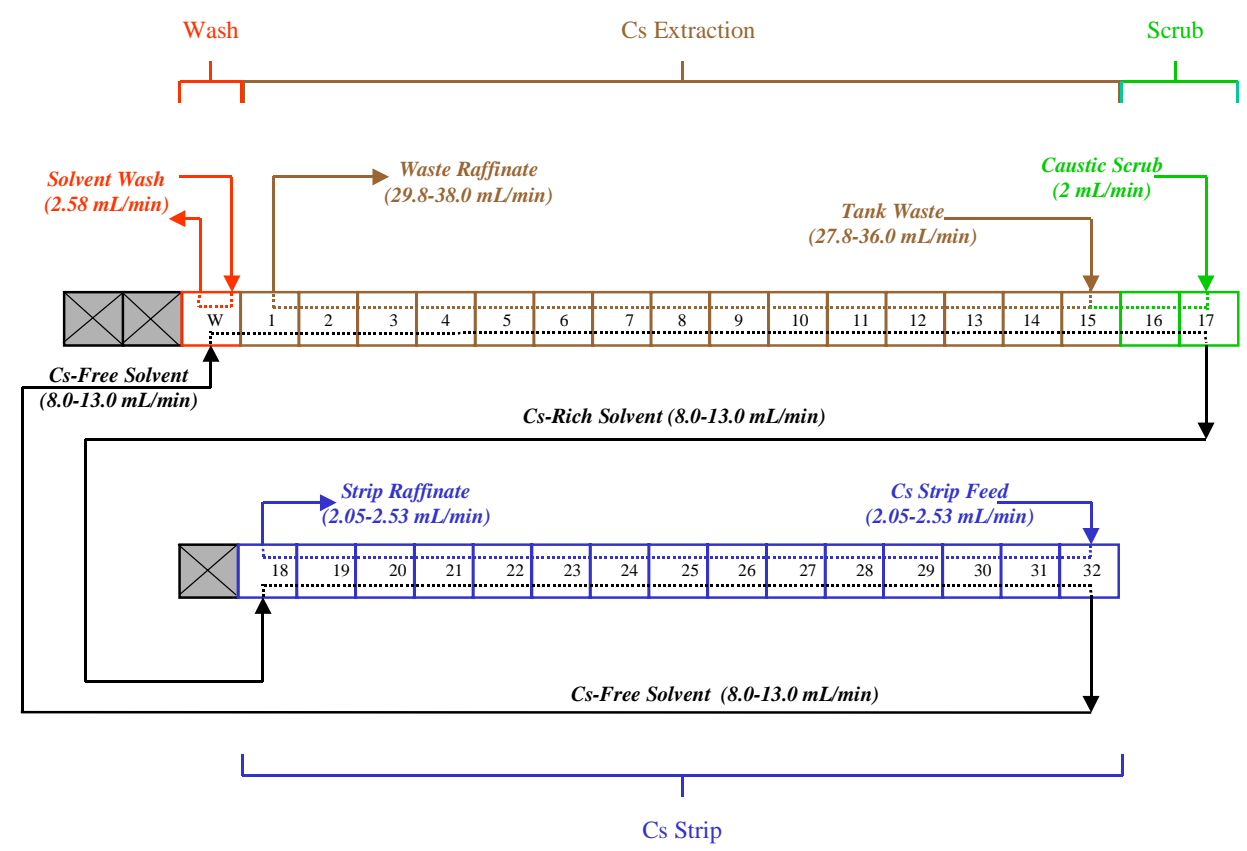

\section{FIGURE 1. Flow Diagram}

earlier tests, data were written to the computer hard drive every four hours and manually backed up to a second hard drive every six hours. Archiving to compact disk occurred every 24 hours.

The filtered Tank $37 \mathrm{H}$ waste was pumped to a $25-\mathrm{L}$ waste feed tank from which it was metered into the contactor apparatus with the Fluid Metering pumps. Aqueous-organic decanters fabricated in the SRTC glass shop received the exit stream from the contactors, disengaged the two phases, and allowed measurement of second-phase carryover.

Balances under the waste feed, scrub feed, and strip feed tanks provided an alternative method for measuring process stream flow rates in previous tests. In this test, the balance under the scrub feed tank failed and was removed. Also, repositioning of the feed tanks facilitated viewing of operations. Figure 2 shows the equipment layout specific to this test and Figure 3 shows the contactor apparatus.

\subsection{EXPERIMENTAL OPERATIONS}

Researchers operated the solvent extraction contactor apparatus following a Waste Processing Technology Section operating procedure. ${ }^{9}$ The following summarizes portions of this procedure relating to normal test operation.

The solvent extraction process operates with the aqueous phase continuous. To initiate an experiment, personnel start the contactor rotors with the wash, scrub, and strip stages filled with wash $(0.01 \mathrm{M} \mathrm{NaOH})$, scrub $\left(0.05 \mathrm{M} \mathrm{HNO}_{3}\right)$, and strip $\left(0.001 \mathrm{M} \mathrm{HNO}_{3}\right)$ solutions, 
WSRC-TR-2002-00307, REV. 0

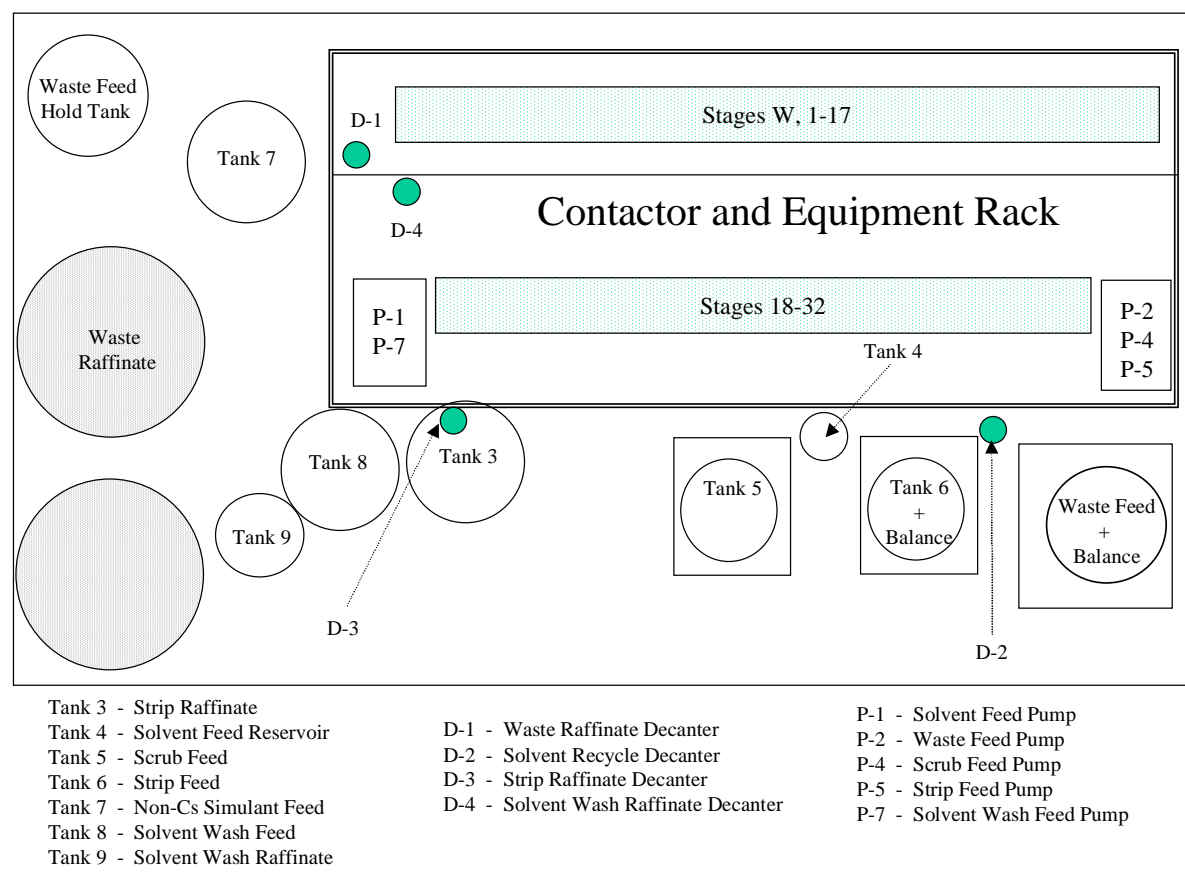

FIGURE 2. Equipment Layout Diagram

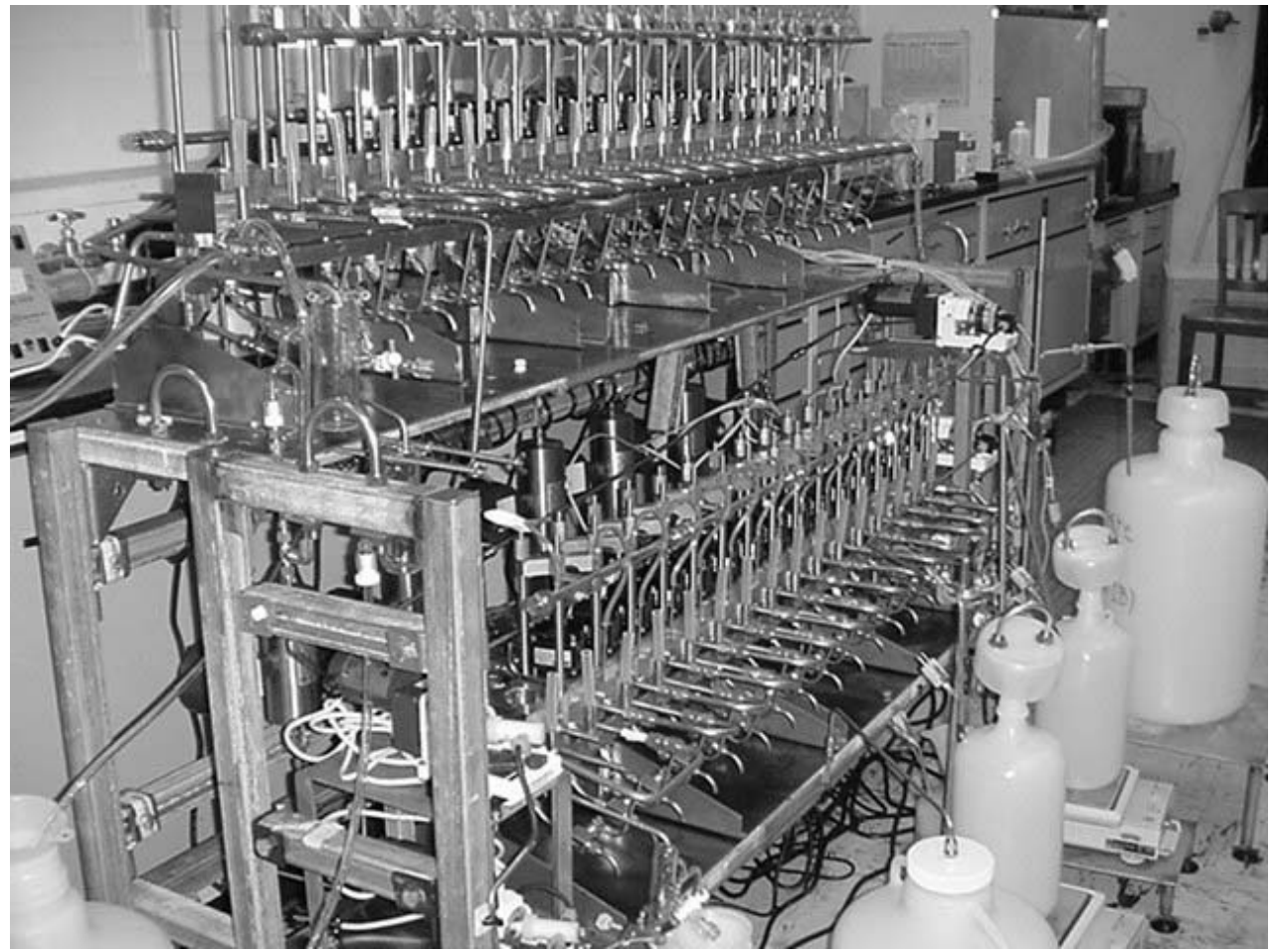

FIGURE 3. General Contactor Configuration. 
respectively. With the wash, scrub, and strip feeds running, startup simulant flow initiates in the extraction bank at Stage 15. Startup uses simulated waste solution containing no cesium. After achieving steady aqueous flow through the extraction stages (Stages 1 to 15), the solvent feed to the wash stage begins. When solvent exits the final strip stage (Stage 32) the aqueous feed switches from the cesium-free startup solution to the test solution.

During tests, researchers monitored the test apparatus or calculated the following at the monitoring intervals indicated in parentheses.

- Motor rotation (15 minutes)

- Liquid in standpipes (15 minutes)

- Feed and collection tank levels (30 minutes).

- Decanter levels (1 hour)

- Temperature trends (1 hour)

- Flow rate trends (1 hour)

- Measured process stream flow rates from timed collection volumes (at direction of the technical lead).

- Calculated and compared flow rates from timed collection data and balance data (1 hour or as directed by the technical lead).

Personnel collected samples by placing sample containers under the outlet points of the continuously-flowing streams. Samples of the solvent feed stream were not taken during the test to avoid disrupting the hydraulic flow conditions.

At the end of each test, researchers stopped the motor rotation and feed pumps simultaneously to minimize disruption of the contents of each stage for the post-test stage samples. Drain valves on each contactor stage allowed removal of each stage's contents at the end of the test.

Equipment flushing followed each test. The extraction stages were flushed with $2 \mathrm{M} \mathrm{NaOH}$ solution to prevent precipitation of aluminum hydroxide in the waste. The strip stages were flushed with strip feed solution $\left(0.001 \mathrm{M} \mathrm{HNO}_{3}\right)$. After flushing with $\mathrm{NaOH}$ or strip feed, all stages were flushed with water.

\subsection{SAMPLING AND ANALYSIS}

Two contactor tests occurred, each with its own objectives and sampling plan. Appendix A provides a copy of the sampling plan developed prior to the test. A Timekeeper Run Sheet containing sample identification, sampling location, and timing was prepared as described in the test procedure.

\subsubsection{Stage Efficiency}

At the end of each test, researchers drained the contents of each stage into polypropylene bottles. Selected samples were transferred to glass separatory funnels, shaken at ambient temperature for 1 minute, then allowed to separate for approximately 16 hours. The final 
temperature was measured and portions of each phase were analyzed for ${ }^{137} \mathrm{Cs}$. The ${ }^{137} \mathrm{Cs}$ concentrations were measured using gamma ray spectroscopic techniques. For low activity samples $\left(<1 \times 10^{7} \mathrm{~d} / \mathrm{m} / \mathrm{mL}\right)$, portions were removed from the shielded facility and counted using ADS routine methods. The ADS method counts $3 \mathrm{~mL}$ of sample for 1000 seconds using an intrinsic germanium solid state detector. For moderate activity aqueous samples $\left(10^{7}\right.$ to $\left.10^{8} \mathrm{~d} / \mathrm{m} / \mathrm{mL}\right)$, aliquots were diluted $\times 10$ or $\times 100$ with water in the shielded facility, and a portion removed for gamma counting. Moderate activity solvent samples were diluted with a solution of 0.5 molar modifier in Isopar ${ }^{\circledR} \mathrm{L}$ solvent. For the high activity samples from the radioactive waste test $\left(>1 \times 10^{8} \mathrm{~d} / \mathrm{m} / \mathrm{mL}\right), 3-\mathrm{mL}$ aliquots were counted using an incell, sodium iodide detector. The sodium iodide detector was calibrated with samples that were diluted, removed from the shielded facility, and counted by the ADS.

\subsubsection{Decontamination and Concentration Factors}

During each test, researchers obtained 5- or 10-mL samples of the three process streams (waste raffinate, strip effluent, and stripped solvent) at intervals of 1 and 2 hours. All samples

were analyzed by ${ }^{137} \mathrm{Cs}$ gamma counting techniques described above. The ratio of the cesium activity in the waste feed to the activity in the waste effluent yields the waste DF. Note that this definition of DF includes dilution of the waste by the scrub solution (e.g, even if processing removes no cesium, the dilution produces a DF of 1.1). Solvent DF equals the ratio of the cesium activity in the waste feed to the activity in the stripped solvent. The CF equals the ratio of cesium activity in the strip effluent to the activity in the waste feed.

\subsubsection{Solvent Entrainment and Degradation}

Researchers estimated the second phase carryover from the volume of solvent that accumulated in the process decanters. Calculations based on the diameter of the decanters and the visually estimated height of the minor-phase layer yielded the volume of the minor phase. Visual estimates of the height of the minor phase are accurate to only $\pm 50 \%$. High performance liquid chromatography (HPLC) analysis of periodic samples of each stream provided concentrations of modifier and extractant. Due to the high ${ }^{137} \mathrm{Cs}$ activity in the strip raffinate samples, they were extracted with dichloromethane in the shielded facility and the extract removed for HPLC analysis.

Solvent degradation was measured on solvent samples taken at the start and end of the test. Modifier and extractant were measured by HPLC. Trioctylamine was measured by gas chromatography with mass spectral detection (GC-MS).

\subsubsection{Minor Components}

Minor inorganic components in the aqueous streams were measured by ICP-ES, inductively coupled plasma mass spectroscopy (ICP-MS), and atomic absorption (AA) methods. Minor organic components were measured as follows: tri- $n$-butyl phosphate (TPB), trimethylamine (TMA), trioctylamine (TOA), dioctylamine (DOA), 4-sec-butylphenol (SBP), and $n$-butanol $(\mathrm{BuOH})$ were measured by GC-MS. 


\subsection{RESULTS}

\subsection{SPIKED SIMULANT TEST}

\subsubsection{Hydraulic Performance}

Researchers performed a 4-hour spiked simulant test prior to the actual waste test to assure proper hydraulic operation of the contactor apparatus and achievement of desired DFs with the dissolved salt cake feed. For this test, personnel spiked $10 \mathrm{~L}$ of simulated Tank $37 \mathrm{H}$ waste with approximately $125 \mathrm{~mL}$ of actual Tank $37 \mathrm{H}$ waste, yielding a radioactive simulant with an average activity of $4.22( \pm .03) \times 10^{7} \mathrm{~d} / \mathrm{m} / \mathrm{mL}$.

The hydraulic portion of the simulant test was especially important in this test campaign because, unlike in previous experiments, the process was operated without the support of a computerized process control system. After almost sixteen months deployed in the shielded facility, the Rheotherm ${ }^{\circledR}$ flowmeters operated unreliably. Radiation exposure or chemical exposure possibly caused the failures. Similarly, radiation exposure disabled the computer controlled chiller used in previous experiments. This situation necessitated the operation of the test rig under manual control for all pumps and the chiller.

Researchers manually calibrated the pumps off-line with the various process fluids prior to the test, and used the resulting calibration curves to determine the desired pump settings. Waste raffinate, solvent, and strip flow rates were checked periodically during the test and necessary adjustments to the pump settings were made. The observed flow rates and corresponding pump settings were then used as initial settings for the actual waste test. Table IV shows the observed waste raffinate and strip feed rates for the spiked simulant test.

As the scrub feed rate could not be directly measured, it was calculated from the scrub feed pump calibration curve to be $2 \mathrm{~mL} / \mathrm{min}$. The scrub feed rate was subtracted from the waste raffinate flow rate to determine the simulant feed rate.

Once the process flows were established, the system operated under stable hydraulic conditions for four hours without interruption.

\section{TABLE IV. Observed Flow Rates for Spiked Simulant Test}

Process Stream

Waste raffinate

Strip solution

\section{Observed Flow (mL/min)}

32.5-33.0

$1.88-2.40$

Page 11 of 39 


\subsubsection{Simulant Decontamination}

During the 4 hours of spiked simulant testing, waste raffinate (i.e., decontaminated waste) samples were collected each hour. The samples were then analyzed by gamma spectrometry, and simulant DFs were calculated. Figure 4 shows the results.

The results in Figure 4 shows that the target DF of 40,000 obtained approximately 2.75 hours after initiating radioactive feed. The target DF was then maintained throughout the remainder of the spiked simulant test. Based on the DF results and stable hydraulic operation during the test, researchers decided to proceed with the actual waste testing.

\subsection{TANK 37H WASTE CONTACTOR TEST}

\subsubsection{Hydraulic Performance}

Researchers treated $44.6 \mathrm{~L}$ of Tank $37 \mathrm{H}$ waste in 25.5 hours of testing. The actual waste demonstration consisted of two parts. The first part consisted of 16 hours of operation of the test apparatus at flow conditions (i.e., Organic/Aqueous phase ratio or O/A ratios) consistent with previous test campaigns. The second part consisted of 9.5 hours of operations at a reduced solvent flow, and thus reduced O/A ratios. For the latter part of the test, the decrease in solvent flow rate coincided with a correction to the waste feed flow rate. The waste feed flow rate correction occurred because repeated measurements of the aqueous raffinate stream indicated it was lower than targeted. The first part of the demonstration allowed comparison of system performance with earlier test results. The second part of the demonstration

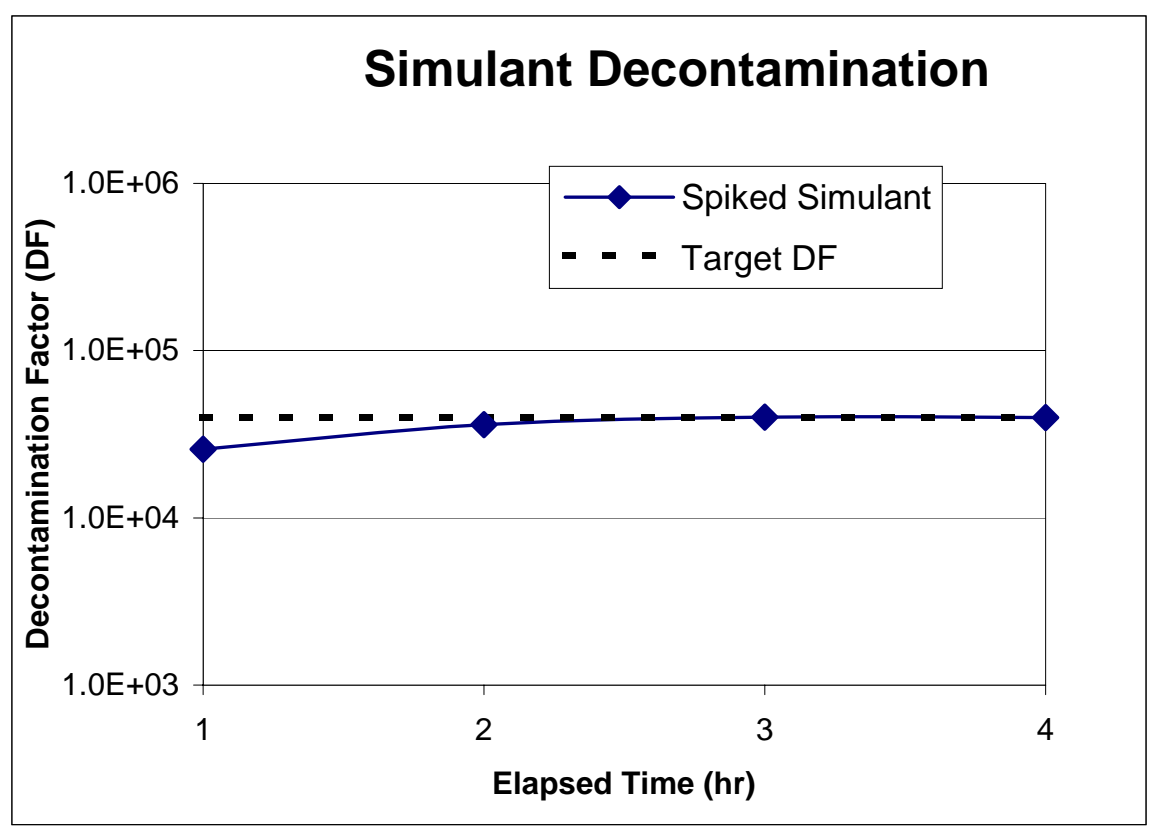

FIGURE 4. Spiked Simulant Decontamination DF Value as a Function of Time. 
allowed examination of system performance under reduced solvent flow rate. Table $\mathrm{V}$ shows the observed process stream flow rates and average O/A ratios during the two phases of testing. Flow rates were measured by timed volumetric collection periodically during the demonstration.

Consistent with the spiked simulant test, the system exhibited excellent, uninterrupted hydraulic performance throughout the 25.5 hours of operation. The average measured solvent flow was $10.6 \pm 1.5 \mathrm{~mL} / \mathrm{min}$ during the initial 16 hours of testing, and $8.3 \pm 0.2 \mathrm{~mL} / \mathrm{min}$ during the remainder of the test. The measured waste raffinate flow averaged $32.3 \pm 2.0$ $\mathrm{mL} / \mathrm{min}$ during the first 16 hours of the test, yielding an extraction section O/A ratio of 0.33 . During the final 9.5 hours, the waste raffinate flow average $36.8 \pm 1.1 \mathrm{~mL} / \mathrm{min}$ yielding an extraction section $\mathrm{O} / \mathrm{A}$ ratio of 0.23 for the second phase of testing. The strip feed averaged $2.3 \pm 0.2 \mathrm{~mL} / \mathrm{min}$ throughout testing, yielding a strip section $\mathrm{O} / \mathrm{A}$ ratio of 4.6 in the first 16 hours and 3.6 in the remainder of the test. Similarly, the solvent wash feed rate of 2.6 $\mathrm{mL} / \mathrm{min}$ (based on a single measurement) yielded a wash section $\mathrm{O} / \mathrm{A}$ ratio of 4.1 during the first 16 hours and 3.2 for the remainder of the test.

\subsubsection{Waste Decontamination}

The ${ }^{137} \mathrm{Cs}$ DF data for the waste in this demonstration show strong process performance throughout the test. DF values displayed a maximum value of 3.35 million, and averaged 352,000 during the first 16 hours of operation. The DFs averaged 28,600 during the final 9 hours of reduced solvent flow operation. Decontamination results for the first 16 hours of the test greatly exceed the process target of 40,000. The DF value for the last 9 hours does not exceed the target but nevertheless produced decontaminated waste that met the Saltstone waste acceptance criterion for ${ }^{137} \mathrm{Cs}$ of $<45 \mathrm{nCi} / \mathrm{g}$. Even with above average ${ }^{137} \mathrm{Cs}$ activity, the Tank $37 \mathrm{H}$ waste required a DF of only 25,800 to meet the Saltstone WAC. Figure 5 shows a plot of the waste DF values as a function of elapsed time. The data point at 4 hours appears anomalously low. No process upsets occurred in that time period and a reanalysis of the sample proved the original result correct. It is likely that the sample was contaminated during handling.

TABLE V. Observed Flow Rates and O/A Ratios

\begin{tabular}{|l|l|l|l|l|}
\hline $\begin{array}{l}\text { PROCESS } \\
\text { STREAM }\end{array}$ & $\begin{array}{l}\text { AVERAGE } \\
\text { OBSERVED } \\
\text { FLOW } \\
\text { 0-16 hours }\end{array}$ & $\begin{array}{l}\text { AVERAGE } \\
\text { O/A RATIO }\end{array}$ & $\begin{array}{l}\text { AVERAGE } \\
\text { OBSERVED } \\
\text { FLOW } \\
\mathbf{1 6 - 2 5 . 5} \text { hours }\end{array}$ & $\begin{array}{l}\text { AVERAGE } \\
\text { O/A RATIO }\end{array}$ \\
\hline Waste Raffinate & $32.3 \mathrm{~mL} / \mathrm{min}$ & $\begin{array}{l}0.33 \\
\text { (Extraction) }\end{array}$ & $36.8 \mathrm{~mL} / \mathrm{min}$ & $\begin{array}{l}0.23 \\
\text { (Extraction) }\end{array}$ \\
\hline Solvent & $10.6 \mathrm{~mL} / \mathrm{min}$ & ------------- & $8.3 \mathrm{~mL} / \mathrm{min}$ & --------------- \\
\hline Strip & $2.3 \mathrm{~mL} / \mathrm{min}$ & $4.6($ Strip) & $2.3 \mathrm{~mL} / \mathrm{min}$ & $3.6($ Strip) \\
\hline Solvent Wash & $2.6 \mathrm{~mL} / \mathrm{min}$ & $4.1($ Wash) & $2.6 \mathrm{~mL} / \mathrm{min}$ & $3.2($ Wash $)$ \\
\hline
\end{tabular}




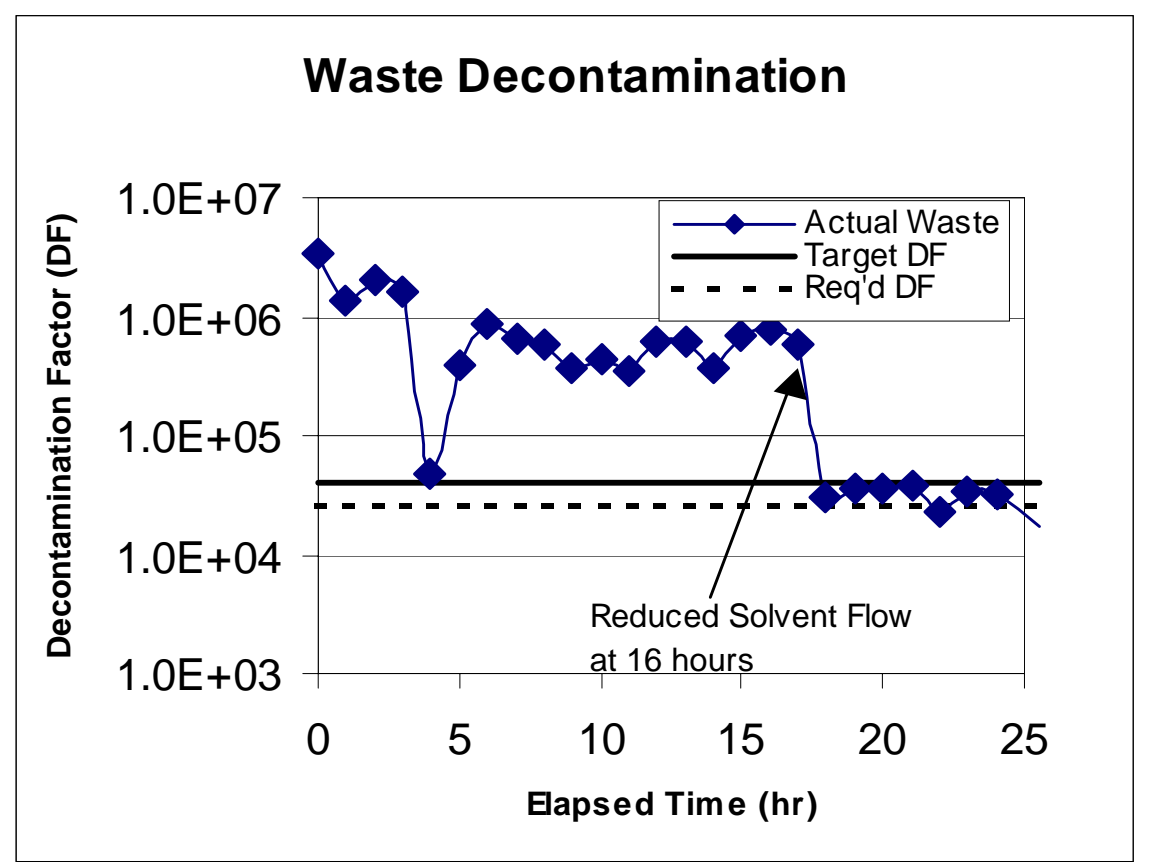

FIGURE 5. Waste DF Value as a Function of Elapsed Time.

\subsubsection{Solvent Decontamination}

Solvent DFs displayed a maximum value of 1.53 million and a minimum value of 5,200 over the course of the actual waste demonstration. Solvent DFs averaged 22,100 over the first 16 hours of testing at nominal solvent flow conditions and 114,000 over the remaining 9 hours at reduced solvent flow. Figure 6 shows a plot of solvent DF values as a function of time during the test.

\subsubsection{Concentration Factors}

Concentration factors measured for the actual waste demonstration indicate steady state was achieved approximately 5 hours after the test began. The average CF value in this phase of testing was approximately 13. This is somewhat lower than the desired value of 15 . At 16 hours, researchers increased the waste feed flow rate and decreased the solvent flow rate causing the CF to increase fairly rapidly to an average value of nearly 16 in the final hours of the test. Again, the $\mathrm{CF}$ achieved a new steady state value within 5 to 6 hours of the flow rate changes. Figure 7 shows a plot of the $\mathrm{CF}$ values as a function of time during the test. 


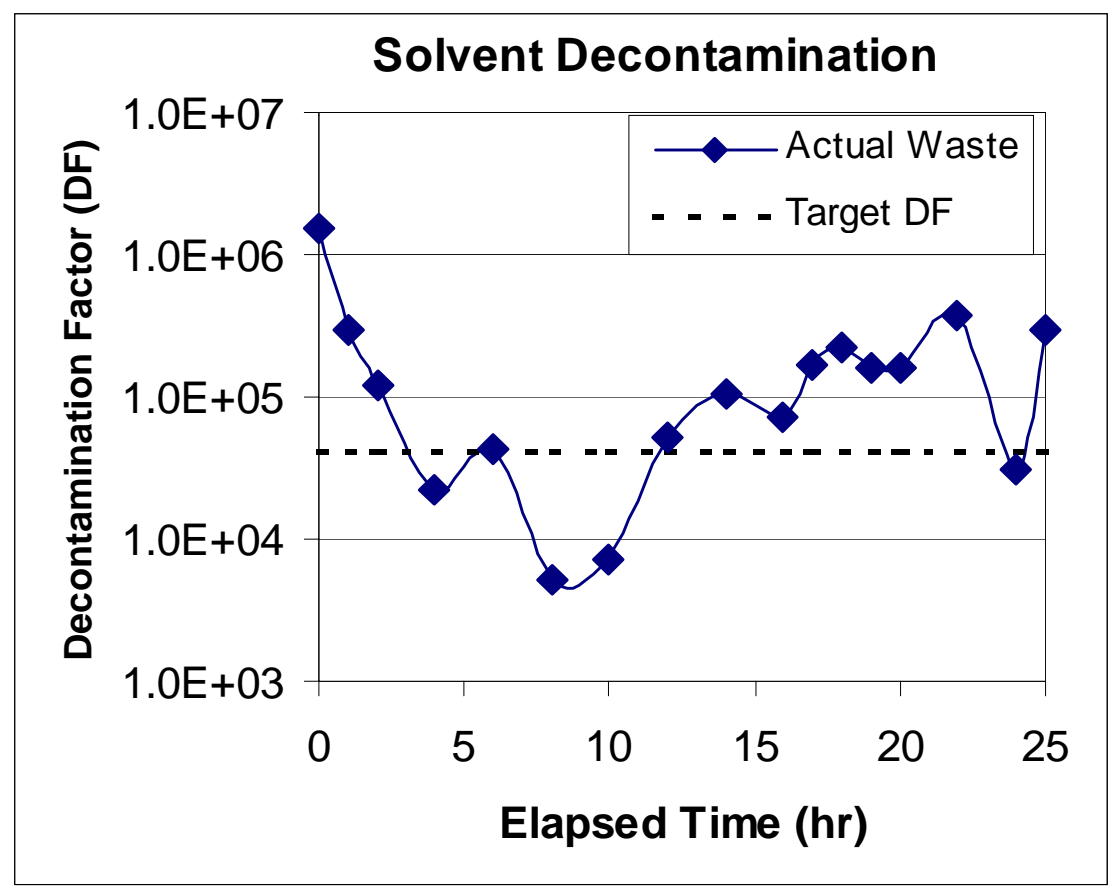

FIGURE 6. Solvent DF Values as a Function of Elapsed Time.

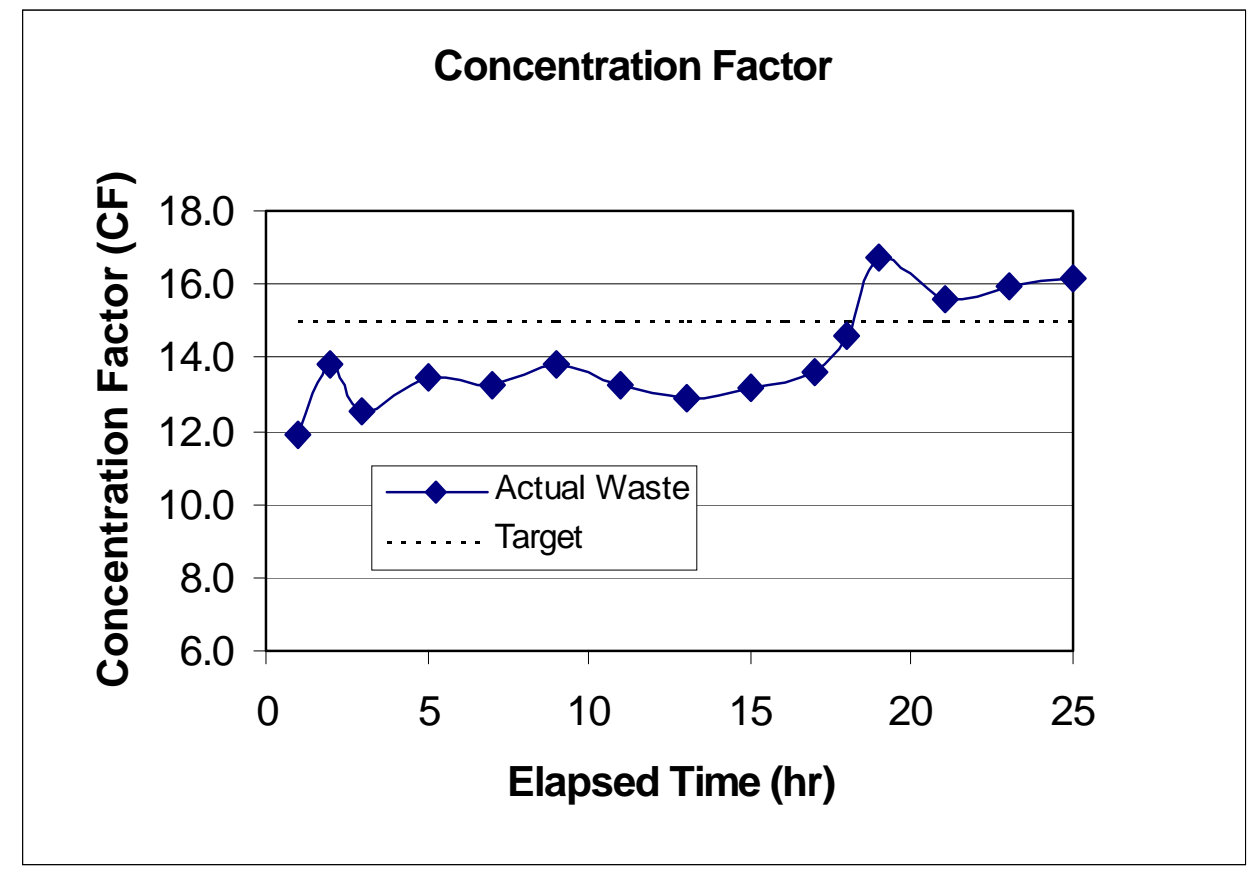

FIGURE 7. CF Values as a Function of Time. 


\subsubsection{Second Phase Carryover}

Researchers estimated the second phase carryover for the Tank $37 \mathrm{H}$ waste test from the volume of solvent (or aqueous) that accumulated in the process decanters during the 24-hour test duration. Table VI lists the estimated minor phase volume in each decanter and the calculated carryover for each stream.

The majority of the minor phase carryover is expected to accumulate in the decanters. However, entrainment of small droplets and solubility losses will escape the decanters. These loses can be detected in the process stream leaving the decanter. Table VII lists results of measurements of solvent components in the aqueous streams leaving the decanters (D1, D3 , and D-4). These represent solvent losses in addition to the carryover amounts listed in Table VI.

TABLE VI. Second Phase Carryover for Tank 37H Waste Test

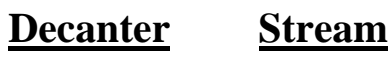

D-1 Waste raffinate

D-2

D-3

D-4
Solvent

Strip raffinate

Wash raffinate
Accumulated

Volume

$\underline{(\mathbf{m L})}$

$<2.9$

$<3.2$

2.2

4.8
Carryover*

(vol \%)
$<0.006$
$<0.02$
0.07
0.16

*Calculated based on the following flow rates during the 24-hour test: Waste raffinate, 32 $\mathrm{mL} / \mathrm{min}$; Solvent, $10.6 \mathrm{~mL} / \mathrm{min}$; and Strip and Wash raffinate, $2.1 \mathrm{~mL} / \mathrm{min}$.

\section{TABLE VII. Solvent Components in Aqueous Process Streams}

\begin{tabular}{|c|c|c|c|c|}
\hline Stream & $\begin{array}{l}\text { Elapsed } \\
\text { Time (h) } \\
\end{array}$ & $\begin{array}{l}\text { Concen } \\
\text { BOBCa }\end{array}$ & $\begin{array}{l}\text { n }(\mathrm{mg} / \mathrm{L}) \\
\text { Iodifier }\end{array}$ & $\begin{array}{c}\text { Entrainment } \\
(\text { vol\%) }\end{array}$ \\
\hline D-1 Waste raffinate & 1 & $<10$ & 29 & 0.012 \\
\hline & 11 & $<10$ & 20 & 0.008 \\
\hline & 23 & $<10$ & 44 & 0.017 \\
\hline D-3 Strip raffinate & 3 & $<5$ & 26 & 0.010 \\
\hline & 14 & 5.5 & 129 & 0.051 \\
\hline & 24 & $<8$ & 39 & 0.016 \\
\hline D-4 Wash raffinate & 2 & $<10$ & 29 & 0.012 \\
\hline & 12 & $<10$ & 25 & 0.010 \\
\hline & 24 & $<10$ & 11 & 0.004 \\
\hline
\end{tabular}




\subsubsection{Solvent Condition and Impurities}

Operators obtained solvent samples at the start and after 24 hours. Table VIII lists results of analyses for the solvent components and impurities. The nominal solvent composition contains $7 \mathrm{mM}$ BOBCalix, $0.75 \mathrm{M}$ modifier, and $3.0 \mathrm{mM}$ trioctylamine. The solvent turned over 10.6 times during the 25.5-hour test.

\subsubsection{Organic Compounds in Aqueous Streams}

Waste raffinate, strip effluent, and solvent wash solution samples were analyzed for minor organic compounds by GC-MS methods. Table IX lists the results. In almost all cases, nothing was found above the detection limit of the analytical method. The 1-hour waste raffinate sample showed minor amounts of TBP and TOA.

\subsubsection{Technetium in Process Streams}

Technetium in solvent streams was measured by ICP-MS or radiochemical counting methods. Table $\mathrm{X}$ lists the results of the analyses.

\section{TABLE VIII. Solvent Composition and Minor Components}

\section{Component}

$\underline{\text { Solvent components }}$

BOBCalix

Modifier

Trioctylamine

$\underline{\text { Solvent degradation products }}$

Dioctylamine

sec-Butylphenol

$\underline{\text { Potential waste components }}$

Trimethylamine

Tributylphosphate

n-Butanol

Radionuclides

${ }^{137} \mathrm{Cs}(\mathrm{d} / \mathrm{m} / \mathrm{mL})$

$\underline{\text { Minor Inorganics }}$

Al

K

$\mathrm{Na}$

$\mathrm{Si}$
$<100 \mathrm{mg} / \mathrm{L}$

$<100 \mathrm{mg} / \mathrm{L}$

$140 \mathrm{mg} / \mathrm{L}$

$<100 \mathrm{mg} / \mathrm{L}$

$<10 \mathrm{mg} / \mathrm{L}$

$5.5 \times 10^{4}$

$<2.5 \mathrm{mg} / \mathrm{L}$

$<5 \mathrm{mg} / \mathrm{L}$

$<0.5 \mathrm{mg} / \mathrm{L}$

$<3.5 \mathrm{mg} / \mathrm{L}$
Final

$6.6 \mathrm{mM}$

$0.71 \mathrm{M}$

$2.8 \mathrm{mM}$

$<100 \mathrm{mg} / \mathrm{L}$

$<100 \mathrm{mg} / \mathrm{L}$

$110 \mathrm{mg} / \mathrm{L}$

$<100 \mathrm{mg} / \mathrm{L}$

$<100 \mathrm{mg} / \mathrm{L}$

$8.8 \times 10^{4}$

$<2.5 \mathrm{mg} / \mathrm{L}( \pm 40 \%)$

$<5 \mathrm{mg} / \mathrm{L}$

$<0.5 \mathrm{mg} / \mathrm{L}$

$<3.5 \mathrm{mg} / \mathrm{L}( \pm 21 \%)$ 
TABLE IX. Organic Compounds in Aqueous Streams

\begin{tabular}{|c|c|c|c|c|c|c|c|}
\hline \multirow[t]{2}{*}{$\underline{\text { Stream }}$} & \multicolumn{3}{|c|}{ Elat } & \multicolumn{4}{|c|}{ Concentration $(\mathrm{mg} / \mathrm{L})$} \\
\hline & & $\underline{\mathrm{BuOH}}$ & TBP & TOA & $\underline{\text { DOA }}$ & $\underline{\text { TMA }}$ & $\underline{\text { SBP }}$ \\
\hline \multirow{3}{*}{ Waste raffinate } & 1 & $<0.1$ & 6.8 & 0.12 & $<0.1$ & $<0.1$ & $<0.1$ \\
\hline & 11 & $<0.1$ & $<0.1$ & $<0.1$ & $<0.1$ & $<0.1$ & $<0.1$ \\
\hline & 23 & $<0.1$ & $<0.1$ & $<0.1$ & $<0.1$ & $<0.1$ & $<0.1$ \\
\hline \multirow[t]{3}{*}{ Strip effluent } & 3 & $<0.12$ & $<0.12$ & $<0.12$ & $<0.12$ & $<0.12$ & $<0$ \\
\hline & 15 & & $<0.17$ & $<0.17$ & $<0.17$ & $<0.17$ & $<0$ \\
\hline & 23 & $<0.21$ & $<0.21$ & $<0.21$ & $<0.21$ & $<0.21$ & $<0$. \\
\hline \multirow[t]{3}{*}{ Solvent wash } & 2 & $<0.1$ & $<0.1$ & $<0.1$ & $<0.1$ & $<0.1$ & $<0$ \\
\hline & 12 & $<0.1$ & $<0.1$ & $<0.1$ & $<0.1$ & $<0.1$ & $<0.1$ \\
\hline & 24 & $<0.1$ & $<0.1$ & $<0.1$ & $<0.1$ & $<0.1$ & $<0.1$ \\
\hline
\end{tabular}

TABLE X. Technetium in Process Streams

\begin{tabular}{lc} 
Stream & $\mathbf{9 9} \mathbf{T c}(\mathbf{m g} / \mathbf{L})$ \\
\cline { 2 - 2 } Tank 37H waste feed & 15 \\
Wash solution $(0.01 \mathrm{M} \mathrm{NaOH})$ & 2.1 \\
Solvent & 0.64 \\
Tank 37H decontaminated waste & 15
\end{tabular}

\subsubsection{Stage Data}

The high concentration of ${ }^{137} \mathrm{Cs}$ in the Tank $37 \mathrm{H}$ waste allowed measurement of distribution coefficients in all stages. Table XI lists the calculated cesium concentration data and distribution coefficients $\left(\mathrm{D}_{\mathrm{Cs}}\right)$ from the stage samples drained from the individual stages at the end of the contactor test. The cesium distribution data were measured at $22.7^{\circ} \mathrm{C}$ (Stages 1 through 9 and 26 through 32 ) and at $26.4{ }^{\circ} \mathrm{C}$ (Stages 11 through 24). The $\mathrm{D}_{\mathrm{Cs}}$ values were corrected to the stage temperatures measured during the test (see Section 5.3.10) using the following enthalpies measured by L. H. Delmau of ORNL for the optimized solvent: extraction, - $48.9 \mathrm{~kJ} / \mathrm{mole}$; first scrub, $-86.8 \mathrm{~kJ} / \mathrm{mole}$; second scrub, $-74.2 \mathrm{~kJ} / \mathrm{mole}$; and strip, $81.1 \mathrm{~kJ} / \mathrm{mole}$. These are similar to previously reported temperature dependence data for the older solvent composition. ${ }^{10}$

Wilmarth ${ }^{11}$ measured $\mathrm{D}_{\mathrm{Cs}}$ values in batch distribution tests using diluted Tank $37 \mathrm{H}$ waste. Table XII compares extraction, scrub, and strip $\mathrm{D}_{\mathrm{Cs}}$ values from Wilmarth and from the stage samples. His extraction $\mathrm{D}_{\mathrm{Cs}}$ value (9.0) was slightly lower than predicted (11.9) for the Tank $37 \mathrm{H}$ waste composition by ORNL researchers. The ORNL model is based on the optimized solvent composition used in the Tank 37 waste test. ${ }^{12}$ 
WSRC-TR-2002-00307, REV. 0

TABLE XI. Stage Sample Cesium Distribution Coefficients

\begin{tabular}{|c|c|c|c|c|c|c|}
\hline \multirow[t]{2}{*}{ Process } & \multirow[t]{2}{*}{$\underline{\text { Stage }}$} & \multicolumn{2}{|c|}{ Cs Concentration (M)* } & \multicolumn{3}{|c|}{$\mathbf{D}_{\mathrm{Cs}}\left(\right.$ at $\left.^{\circ} \mathbf{C}\right)$} \\
\hline & & $\underline{\text { Aqueous }}$ & Organic & \multicolumn{2}{|c|}{$\begin{array}{l}\text { Stage } \\
\text { Sample }\end{array}$} & $\begin{array}{c}\text { Corrected } \\
\text { for efficiency calc }\end{array}$ \\
\hline \multirow{8}{*}{ Extraction } & 1 & 9.4E-9 & $1.4 \mathrm{E}-7$ & $1 \overline{5.3}$ & $(22.7)$ & $15.2(23)$ \\
\hline & 3 & $6.2 \mathrm{E}-8$ & $8.0 \mathrm{E}-7$ & 13.0 & $(22.7)$ & $12.9(23)$ \\
\hline & 5 & 3.0E-7 & $4.0 \mathrm{E}-6$ & 13.2 & (22.7) & $13.1 \quad(23)$ \\
\hline & 7 & $1.7 \mathrm{E}-6$ & $1.3 \mathrm{E}-5$ & 7.7 & (22.7) & $7.6 \quad(23)$ \\
\hline & 9 & $1.3 \mathrm{E}-5$ & $5.2 \mathrm{E}-5$ & 4.1 & (22.7) & $4.1 \quad(23)$ \\
\hline & 11 & $2.5 \mathrm{E}-5$ & $6.5 \mathrm{E}-4$ & 26.0 & $(26.4)$ & 31.9 (23) \\
\hline & 13 & $9.6 \mathrm{E}-5$ & 8.3E-4 & 8.6 & $(26.4)$ & $10.6 \quad(23)$ \\
\hline & 15 & $8.5 \mathrm{E}-4$ & $2.9 \mathrm{E}-3$ & 3.4 & $(26.4)$ & $4.2 \quad(23)$ \\
\hline \multirow[t]{2}{*}{ Scrub } & 16 & $2.5 \mathrm{E}-3$ & $2.1 \mathrm{E}-3$ & 0.8 & $(26.4)$ & $0.46 \quad(34)$ \\
\hline & 17 & $3.8 \mathrm{E}-3$ & $2.6 \mathrm{E}-3$ & 0.6 & $(26.4)$ & $0.37 \quad(34)$ \\
\hline \multirow[t]{8}{*}{ Strip } & 18 & 4.9E-3 & $2.2 \mathrm{E}-3$ & 0.4 & (26.4) & $0.17 \quad(39)$ \\
\hline & 20 & $2.5 \mathrm{E}-3$ & $3.3 \mathrm{E}-4$ & 0.1 & $31(26.4)$ & 0.048 (39) \\
\hline & 22 & $1.3 \mathrm{E}-3$ & $6.4 \mathrm{E}-5$ & 0.0 & $00(26.4)$ & 0.018 (39) \\
\hline & 24 & $2.3 \mathrm{E}-4$ & $9.0 \mathrm{E}-6$ & 0.0 & $39(26.4)$ & 0.014 (39) \\
\hline & 26 & $9.7 \mathrm{E}-6$ & $1.1 \mathrm{E}-6$ & & $8(22.7)$ & 0.032 (39) \\
\hline & 28 & $1.2 \mathrm{E}-6$ & $5.0 \mathrm{E}-7$ & 0.4 & $(22.7)$ & $0.11 \quad(39)$ \\
\hline & 30 & $4.8 \mathrm{E}-8$ & $5.4 \mathrm{E}-9$ & & $4(22.7)$ & 0.031 (39) \\
\hline & 32 & $1.2 \mathrm{E}-7$ & $8.7 \mathrm{E}-8$ & 0.7 & $(22.7)$ & $0.19 \quad(39)$ \\
\hline
\end{tabular}

*The cesium distribution data were measured at $22.7^{\circ} \mathrm{C}$ (Stages 1 through 9 and 26 through 32) and at $26.4^{\circ} \mathrm{C}$ (Stages 11 through 24).

Researchers estimated the stage efficiencies by comparing the cesium concentration data in Table XI to calculated concentrations obtained from the Spreadsheet Algorithm for Stagewise Solvent Extraction (SASSE). ${ }^{13}$ Input data for the SASSE calculations include flow rates, cesium concentrations in feed streams, cesium distribution coefficients, and stage efficiencies. Since the $\mathrm{D}_{\mathrm{Cs}}$ values in Table XI were erratic, values for Tank $37 \mathrm{H}$ waste and the optimized solvent were taken from Wilmarth ${ }^{11}$ (Table XII) and corrected to the averaged surface temperatures measured on the contactors (Table XIII). SASSE-calculated cesium concentrations for each stage at 5\% efficiency increments were compared to the measured stage concentrations. The comparison is based on the slope of the lines through the predicted and measured values and not on the overlap of the predicted values with the measured data points. The slopes match well with extraction stage efficiencies of $90 \%$ and strip stage efficiencies of $80 \%$. However, this yields poor agreement between the measured and calculated cesium concentrations in stages 20 and 22. Figure 8 shows the SASSE results when the $\mathrm{D}_{\mathrm{Cs}}$ values for stages 18 to 22 are adjusted so that the calculated and measured values agree. Figure 8 also contains the waste raffinate, strip effluent, and stripped solvent cesium concentrations from the end of the test, plotted against the stage from which the streams exit the contactor apparatus. Table XIII lists the parameter values used in the calculation. 
TABLE XII. Cesium Distribution Coefficients for Tank 37H Waste*

$\underline{\text { Operation }}$

Extraction

Scrub 1

Scrub 2

Strip 1

Strip 2

Strip 3

* At $25^{\circ} \mathrm{C}$.

** See Reference 11 .

*** From Table XI, corrected to $25^{\circ} \mathrm{C}$.

\section{Stage Samples***}

$10.9 \pm 8.0$

0.98

0.79

0.52

$0.19 \pm 0.19$

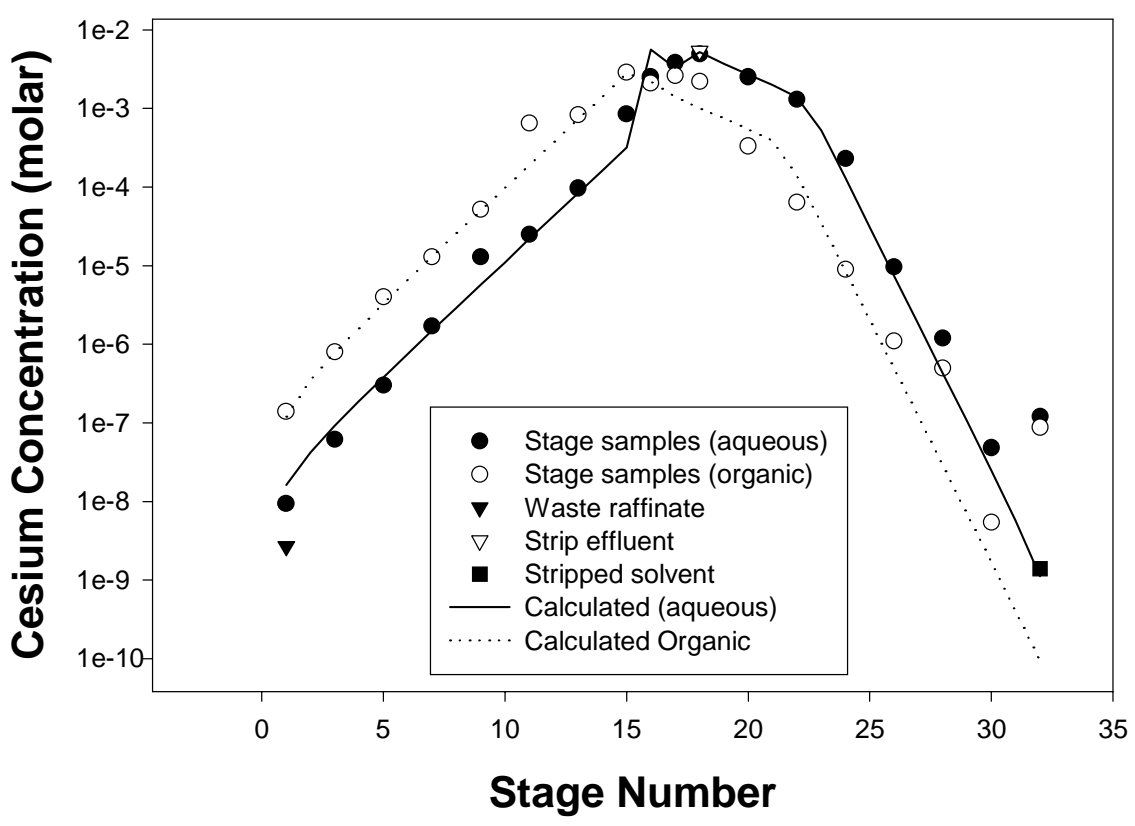

FIGURE 8. Comparison of Stage Sample Data and SASSE Calculated Concentrations 
WSRC-TR-2002-00307, REV. 0

TABLE XIII. Parameter Values Used in SASSE Calculation

$\begin{array}{llccc}\text { Section } & \text { Stages } & \begin{array}{c}\text { Temperature } \\ \left({ }^{\circ} \mathbf{C}\right)\end{array} & \underline{\mathbf{D}}_{\mathbf{C S}} & \begin{array}{c}\text { Efficie } \\ \underline{(\boldsymbol{\%})}\end{array} \\ \text { Extraction } & 1 \text { through } 15 & 23 & 10.3^{*} & 90 \\ \text { Scrub } & 16 & 34 & 0.34^{*} & 80 \\ & 17 & 34 & 0.30^{*} & 80 \\ \text { Strip } & 18 & & 0.17^{* *} & 80 \\ & 19 & & 0.17^{* *} & 80 \\ & 20 & & 0.17^{* *} & 80 \\ & 21 & & 0.17^{* *} & 80 \\ & 22 & 39 & 0.05^{* *} & 80 \\ & 23 \text { through 32 } & & 0.012^{*} & 80\end{array}$

*Wilmarth $\mathrm{D}_{\mathrm{Cs}}$ data corrected using optimized solvent enthalpy values to the temperature listed.

** $\mathrm{D}_{\mathrm{Cs}}$ values adjusted so that SASSE calculations fit stage sample cesium concentration data.

\subsubsection{Stage Temperatures}

Thermocouples attached to the outside of contactor stages in each section of the test apparatus measured temperatures during the test campaign. The temperatures in each section remained fairly stable within the ranges shown in Table XIV. It should be noted that the wash stage temperature is included in the extraction section temperature range.

TABLE XIV. Temperature Ranges for Contactor Sections.

\begin{tabular}{|l|l|l|}
\hline $\begin{array}{c}\text { Contactor } \\
\text { Section }\end{array}$ & \multicolumn{1}{|c|}{ Target $\left({ }^{\circ} \mathbf{C}\right)$} & $\begin{array}{c}\text { Temperature } \\
\text { Range }\left({ }^{\circ} \mathbf{C}\right)\end{array}$ \\
\hline Extraction & $>20$ and $<25$ & $20.9-26.0$ \\
\hline Scrub & $>20$ & $32.0-37.3$ \\
\hline Strip & $>20$ & $35.0-42.1$ \\
\hline
\end{tabular}


WSRC-TR-2002-00307, REV. 0

\subsection{DISCUSSION}

\subsection{TANK 37H WASTE COMPOSITION}

The Tank $37 \mathrm{H}$ dissolved salt waste composition proved similar to previously studied supernatant solutions. Crystallization of less soluble salts leaves waste supernatant solutions highly concentrated in sodium hydroxide. Free hydroxide accounts for half or more of the total sodium concentration. Dilution with $1.6 \mathrm{M} \mathrm{NaOH}$ also contributes to the high hydroxide concentration in the final waste solution. After dilution, the Tank $37 \mathrm{H}$ waste contained $3.7 \mathrm{M}$ free hydroxide compared to $2.0 \mathrm{M}$ free hydroxide in average waste. ${ }^{14}$ Nitrate $(0.73 \mathrm{M})$ is correspondingly low compared to the expected average concentrations $(1.7 \mathrm{M})$. Cesium also concentrates in the supernate. This is reflected in the high ${ }^{137} \mathrm{Cs}$ activity of the diluted sample $\left(3.2 \times 10^{9} \mathrm{~d} / \mathrm{m} / \mathrm{mL}\right.$ or $\left.1.4 \mathrm{Ci} / \mathrm{L}\right)$ compared to average waste $(0.37$ $\mathrm{Ci} / \mathrm{L})$. Potassium ion $(0.039 \mathrm{M})$, which competes with cesium during extraction, is also higher than average $(0.014 \mathrm{M})$. The high concentrations of these two components makes decontamination of the Tank $37 \mathrm{H}$ waste more challenging than average waste.

\subsection{HYDRAULIC PERFORMANCE}

The contactor test apparatus operated without interruption in a hydraulically stable condition throughout both the 4-hour spiked simulant test and 25.5-hour actual waste demonstration. This was achieved through manual control without the assistance of the computerized feedback control system employed in previous experiments. Sixteen months of storage in the shielded facility resulted in unreliable operation of the Rheotherm ${ }^{\circledR}$ flowmeters and failure of the computer controlled chillers. Researchers calibrated all process pumps with the process liquids and constructed pump speed calibration curves. During the tests, periodic timed collection of the various process liquids provided flow rates. Pumps were then manually adjusted based on the calibration curves. Timed collection of process liquids had to be made at points where process streams exited the test apparatus so as to avoid hydraulic upset by interrupting feeds. Therefore, direct flow measurement was possible on wash, solvent, and strip streams, but not the scrub or waste. The waste raffinate stream is comprised of a blending of the scrub and waste feeds. The scrub feed pump was initially set to the speed that corresponded to a flow rate of $2 \mathrm{~mL} / \mathrm{min}$ and was held constant throughout the test. The waste feed pump was initially set to the speed that corresponded to a flow rate of $30 \mathrm{~mL} / \mathrm{min}$. Then the waste feed pump speed was adjusted as waste raffinate flow measurements deemed necessary while holding the scrub feed rate constant and assuming its value to be $2 \mathrm{~mL} / \mathrm{min}$. Adjustments attempted to maintain a total aqueous phase flow rate in the extraction section of $32 \mathrm{~mL} / \mathrm{min}$.

In spite of the relatively crude method of flow measurement and control, excellent hydraulic performance of the system resulted. Neither flooding of any stage nor any other interruption of operations occurred during the test. The process flows averaged within $10 \%$ of desired values. However, it took a considerable amount of time to "tune" the flows to the desired values, and variations exceeding $10 \%$ occurred often. 


\subsection{SECOND PHASE CARRYOVER}

Second phase carryover is an unwanted liquid phase exiting in a primary product stream (e.g., the organic solvent exiting in the aqueous waste raffinate stream). Secondary phase carryover is directly related to hydraulic performance. Excessive second phase carryover is indicative of poor hydraulic performance and can lead to large losses of solvent.

Based on measurements performed on all four decanters, second phase carryover was maintained at well below 1 vol $\%$ for the entire test campaign. There was no visible second phase accumulation in either the waste raffinate decanter (D-1) or the stripped solvent decanter (D-2). These observations indicate a second phase carryover that is essentially zero. In the strip raffinate decanter (D-3) and wash receipt decanter (D-4), the second phase carryovers were estimated $0.034 \%$ and $0.12 \%$, respectively. These low values for second phase carryover are another indication of the excellent hydraulic performance observed during the demonstration.

Table XV lists the total second phase carryover based on the decanter measurements (Table VI) and the sample analyses (Table VII). In all cases, minor phase carryover in all process streams was maintained well below the process objective of $<1.0 \mathrm{vol} \%$. The losses that escape the decanter may be due to entrainment that was not captured by the decanter or to the solubility of solvent components in the aqueous process stream. The observed values greatly exceed the partition coefficients ${ }^{15}$ previously measured for solvent components in simulated waste, suggesting that the compounds are present due to entrainment rather than solubility. The measured partition coefficients suggest that modifier concentrations due to solubility should be less than $5 \mathrm{mg} / \mathrm{L}$.

\subsection{WASTE AND SOLVENT DECONTAMINATION}

One of the main indicators of process performance is the waste DF. Waste feed entering Stage 15 is blended with scrub solution, contacted with the solvent, and exits Stage 1. The degree of extraction is affected by hydraulic performance, stage temperature,

TABLE XV. Combined Minor Phase Carryover Results*

$\begin{array}{clcll}\text { Decanter } & \text { Stream } & \begin{array}{l}\text { Decanter } \\ \text { (vol \%) }\end{array} & \begin{array}{l}\text { Maximum } \\ \text { Entrainment } \\ (\text { vol\%) }\end{array} & \begin{array}{l}\text { Total } \\ \text { (vol \%) }\end{array} \\ \text { D-1 } & \text { Waste raffinate } & <0.006 & 0.017 & \leq 0.023 \\ \text { D-2 } & \text { Solvent } & <0.02 & -- & <0.02 \\ \text { D-3 } & \text { Strip raffinate } & 0.07 & 0.051 & 0.12 \\ \text { D-4 } & \text { Wash raffinate } & 0.16 & 0.012 & 0.17\end{array}$

*See Tables VI and VII. 
stage efficiency, and residual cesium concentration in the solvent feed. The DF required for Tank $37 \mathrm{H}$ waste to meet the Saltstone waste acceptance criterion for ${ }^{137} \mathrm{Cs}(<45 \mathrm{nCi} / \mathrm{g})$ equaled 25,800. The higher target DF of 40,000 ensures ample process robustness and allows comparison of system performance with previous test campaigns.

Solvent decontamination in the stripping section is also important. If sufficient stripping of the cesium-loaded solvent does not occur (low solvent DFs) cesium in the solvent is recycled back to the contactor bank and reduces the maximum attainable waste DF. Again, the higher target DF of 40,000 ensures ample process robustness and allows comparison of system performance with previous test campaigns.

\subsubsection{Spiked Simulant Testing}

The spiked simulant DF results verified that radioactive operations could be successfully performed with the new dissolved salt cake feed. The DF values approached the target value of 40,000 within three hours of operation. This demonstrated that, not only was decontamination of the new feed type possible, but also that the sampling procedure was adequate to avoid sample contamination. The latter point was of particular concern due to high levels of background contamination encountered during test preparation.

\subsubsection{Tank 37H Waste Decontamination}

Waste DFs from both phases of the demonstration show excellent verification of the process efficacy. Waste DF values as high as 3 million were achieved during the first 16 hours of operation with an average DF value of 352,000 . This average DF value is 8.8 times greater than the target DF value of 40,000 and 13.5 times the required DF value of 25,800 to meet Saltstone waste acceptance criterion. The first 16 hours of operation occurred at nominal flow conditions and $\mathrm{O} / \mathrm{A}$ ratios that are similar to those used in previous test campaigns. The final 9.5 hours of operation occurred at reduced solvent flow and increased waste feed flow conditions while holding other flow rates constant. Researchers expected that reducing the extraction section O/A ratio would reduce the observed waste DF values. This did, indeed, occur. However, even at the reduced solvent flow that decreased the extraction section O/A from the value of 0.33 to 0.23 , the process still achieved an average DF value 28,600 . This value exceeded the required DF value of 25,800 . It should also be noted that the nominal extraction $\mathrm{O} / \mathrm{A}$ value of 0.33 reported here equals the desired nominal $\mathrm{O} / \mathrm{A}$ value.

The acceptable DFs achieved at the reduced O/A ratio in the latter part of the test indicate the robustness of the process to changes in processing conditions. They also show that a given contactor size can process waste faster (without exceeding the contactor capacity) by decreasing the solvent flow rate and increasing the waste feed rate, at the expense of lower (but acceptable) DFs.

\subsubsection{Solvent Decontamination}

Although there was no explicit target solvent DF for this test, previous testing performed in FY-2001 used a target solvent DF of 40,000. The same value serves as a convenient 
reference value for the present test. In addition, solvent DF values exceeded 100,000 in FY2001 testing with the old solvent composition and averaged 400,000 in ANL testing with optimized solvent. ${ }^{16}$

Solvent decontamination in the first 16-hour portion of the test showed a steady decline until about 8 hours. This corresponds to the time interval from the start of the test to the first timed volumetric collection of solvent. The result of that measurement showed that the solvent flow rate was too high. The solvent flow rate was $13 \mathrm{~mL} / \mathrm{min}$, which was $21 \%$ higher than the desired $10.7 \mathrm{~mL} / \mathrm{min}$ flow rate. The elevated solvent flow rate caused the solvent to pass too quickly through the strip section, allowing cesium accumulation in the solvent. This trend in the solvent correlates with the gradual decline in the waste DF from the start of the test until approximately 8 hours. The reduction in solvent flow rate at 8 hours caused the solvent DF to recover by 10 hours. Similarly, at approximately 8 hours, the waste DF appeared to level off and remain almost constant for the duration of the first part of the test. By 16 hours, the solvent DF was almost 72,000, almost twice the target value of 40,000. Upon reducing the solvent flow "set point" to approximately $8.3 \mathrm{~mL} / \mathrm{min}$ at 16 hours, the solvent DF quickly increased to almost 160,000 and achieved values as high as 369,000 during the final 9.5 hours of the test. This is expected as further reduction in the solvent flow rate should further increase the strip section residence time and improve solvent decontamination. The low DF value at 24 hours does not correspond to any process upsets or changes in flow rates and may be due to sample contamination.

It is clear that the initial decline in the solvent DF was not the product of the strip section performing poorly. Rather, it is simply the symptom of the strip section being overwhelmed by an excessive solvent flow rate. The last four hours after the solvent flow was reduced demonstrate that the strip section could, indeed, decontaminate the solvent when operated properly.

\subsubsection{Concentration Factor}

The cesium removed from the waste feed by the solvent is to be stripped from the solvent in the strip section and concentrated in the aqueous strip raffinate. The target concentration factor for cesium in the strip raffinate for this test campaign was a $\mathrm{CF}$ value of 15 . The $\mathrm{CF}$ values for the first 16 hours of the actual waste demonstration average 13.2, implying a $12 \%$ deviation from the target $\mathrm{CF}$ value. The $\mathrm{CF}$ values for the first 16 hours of operation also remain fairly constant in spite of variations in the solvent flow. It is apparent that concentration factor is not a very strong function of solvent flow rate.

The only significant change in $\mathrm{CF}$ comes after the solvent flow "set point" change at 16 hours. Beginning at 17 hours, the $\mathrm{CF}$ begins to increase to an average value of 15.8 in the final 9.5 hours of the test.

It can be shown that the $\mathrm{CF}$ behavior observed during this test is dominated by hydraulic conditions rather than by process chemistry. As has been already mentioned, the need to operate the system under manual control of the pumps introduced considerable error in flow measurement. However, the $\mathrm{CF}$ behavior can be roughly estimated from the available flow 
data and compared to the measured CF data observed from the testing. Figure 9 shows this comparison.

The available strip feed data showed that the strip feed rate never varied by more than approximately $0.25 \mathrm{~mL} / \mathrm{min}$ over the course of the test. So, it can be held constant at the average value $(2.3 \mathrm{~mL} / \mathrm{min})$. The scrub feed pump is the same make and model as the strip feed pump. Although scrub feed data are unavailable, it is reasonable to assume that the scrub feed could be held constant, as well, at its nominal value of $2 \mathrm{~mL} / \mathrm{min}$. There are a considerable amount of waste raffinate flow data available. These data can be corrected to estimate the waste feed rate by subtracting the nominal scrub feed value $(2 \mathrm{~mL} / \mathrm{min})$ from the measured waste raffinate flow data. The $\mathrm{CF}$ can then be estimated by dividing the corrected waste raffinate flow data by the average strip feed rate. When the estimated CF values are plotted together with the measured values, it is found that the two data sets correspond rather closely. When one further considers the error introduced by the simplifying assumptions made in the estimate, it is quite likely that the lower than desired observed CF data (12\% deviation from target) were caused by uncertainty in the flow control, rather than by poor process chemistry performance.

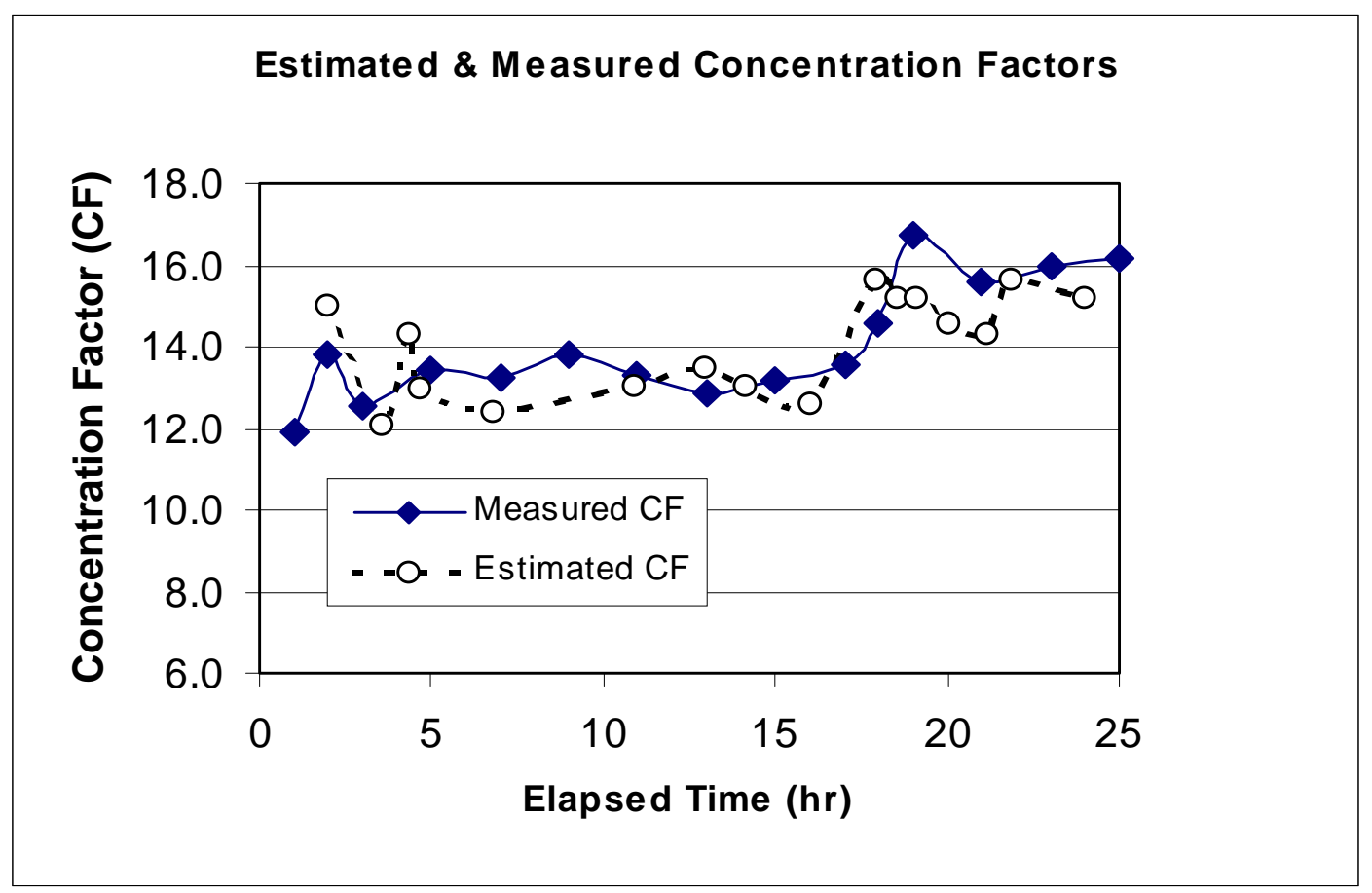

FIGURE 9. Comparison of Estimated and Measured CF Values. 


\subsection{SOLVENT CONDITION AND IMPURITIES}

The solvent condition did not changed significantly during the 25.5 -hour test. The modifier, extractant, and suppressor concentrations at the beginning and end of the test agreed with each other and with the theoretical solvent composition within the error $( \pm 10 \%)$ of the HPLC measurements (Table VIII). The cesium activity in the solvent increased from $5.5 \times 10^{4}$ $\mathrm{d} / \mathrm{m} / \mathrm{mL}$ to $8.8 \times 10^{4} \mathrm{~d} / \mathrm{m} / \mathrm{mL}$ during the test, but the results from the stripped solvent samples indicate a steady state was reached and cesium was not continuing to accumulate in the solvent. With the exception of trimethylamine (TMA), no significant amounts of organic or inorganic impurities were found in either the initial or final solvent samples. TMA was found in both the initial and final solvent samples at levels slightly above the detection limit of the analysis. The Tank $37 \mathrm{H}$ waste was not analyzed for TMA. The low and relatively constant level of TMA in the solvent does not pose a problem to the process. However, the presence of TMA is unexpected because the solvent was new at the start of the simulant test, the simulant did not contain TMA, and acid scrubbing and stripping during waste processing removes TMA. Future testing could attempt to confirm this observation by employing increased quality assurance measures to ensure the sample integrity and analytical accuracy.

\subsection{TECHNETIUM IN PROCESS STREAMS}

Previously, Pennebaker, et al., ${ }^{17}$ reported the presence of $0.2 \mathrm{mg}{ }^{99} \mathrm{Tc} / \mathrm{mL}$ in stripped solvent from the Tank $37 \mathrm{H} / 44 \mathrm{~F}$ composite waste test with optimized solvent. ${ }^{2}$ Results from that test indicated the technetium concentration in the solvent reached a steady state several hours into the test. At the end of the dissolved salt cake test with Tank $37 \mathrm{H}$ waste, the solvent contained $0.64 \mathrm{mg}{ }^{99} \mathrm{Tc} / \mathrm{mL}$ (Table X). The higher concentration compared to that found in the previous test may result from the higher ${ }^{99} \mathrm{Tc}$ concentration in the Tank $37 \mathrm{H}$ waste $(15$ $\mathrm{mg} / \mathrm{L})$ compared to the Tank $37 \mathrm{H} / 44 \mathrm{~F}$ composite waste $(6.5 \mathrm{mg} / \mathrm{L})$. The amount of technetium found in the spent wash solution $(2.1 \mathrm{mg} / \mathrm{L})$, suggests about $1 \%$ of the total technetium is removed (assuming no technetium is removed in the strip solution). Problems from technetium accumulation are unlikely since much of it is removed by the solvent wash solution and the steady state concentration is low (less than $0.1 \%$ of the trioctylamine concentration in the solvent).

\subsection{STAGE SAMPLES}

Testing with Tank $37 \mathrm{H}$ waste enabled measurements of the distribution coefficients for all process stages (Table IX). The averaged results generally agreed with previously measured values, but the individual results were erratic. The distribution coefficients for the extraction stages averaged $10.9 \pm 8.0$ at $25{ }^{\circ} \mathrm{C}$. This compares favorably to the previously reported measured $\left(\mathrm{D}_{\mathrm{Cs}}=9\right.$ at $\left.25{ }^{\circ} \mathrm{C}\right)$ and calculated $\left(\mathrm{D}_{\mathrm{Cs}}=11.9\right.$ at $\left.25{ }^{\circ} \mathrm{C}\right)$ values for Tank $37 \mathrm{H}$ waste. ${ }^{10}$ However, the average value may be somewhat fortuitous since the individual stages varied between 3.5 and 28.5. Because of the large variability in the stage sample D values, the more precise value of Wilmarth was used for the efficiency calculations $\left(\mathrm{D}_{\mathrm{Cs}}=10.3\right.$ at 23 $\left.{ }^{\circ} \mathrm{C}\right)$. The stage sample $\mathrm{D}_{\mathrm{Cs}}$ values for the scrub stages $\left(0.98\right.$ and 0.79 at $\left.25^{\circ} \mathrm{C}\right)$ closely resemble Wilmarth's values $\left(0.94\right.$ and 0.74 at $\left.25{ }^{\circ} \mathrm{C}\right)$. For consistency, Wilmarth's scrub D values were used in the efficiency calculations. The stage sample $\mathrm{D}_{\mathrm{Cs}}$ values for the strip 
stages were also erratic so temperature corrected values based on Wilmarth's results were used in the initial efficiency calculations. Values for stages 19 through 22 were adjusted in later calculations to more closely fit the observed cesium concentrations from the stage samples.

The $90 \%$ efficiency found for the extraction stages agrees well with previously measured values. Leonard ${ }^{16}$ obtained an efficiency of $85 \%$ using $2-\mathrm{cm}$ contactors with the modified solvent and simulated waste. The strip efficiency of $80 \%$ is less than Leonard's value of $92 \%$, but equals the process objective of $80 \%$. Researchers at Idaho National Engineering and Environmental Laboratory have also experienced low strip efficiencies with the optimized solvent in a $5.5-\mathrm{cm}$ contactor, ${ }^{18}$ but at present the problems do not appear to be related. The low solvent and strip flow rates used at the end of the 2-cm contactor test may have resulted in low fluid levels or erratic flow rates that can decrease the strip stage efficiencies. ${ }^{16,19}$ However, measurements of the volume of the stage samples showed approximately $17 \mathrm{~mL}$ per strip stage, which is similar to previous tests showing higher efficiencies. ${ }^{1}$ Shortly after the Tank $37 \mathrm{H}$ waste test, the rotor in stage 21 failed. Erratic performance during the Tank $37 \mathrm{H}$ waste test could have affected the performance of stages 18 through 22 .

The necessity of increasing the strip $\mathrm{D}_{\mathrm{CS}}$ values in stages 18 through 22 to higher values than found by Wilmarth (so that the SASSE calculated cesium concentrations matched the observed stage sample data) suggests a chemical complication. Known causes of poor stripping include improper $\mathrm{pH}$, potassium ion, and certain anions. $\mathrm{pH}$ measurements of the scrub and strip acid did not reveal any problem with the acidity. Other components were not investigated because of the high activity of the strip effluent. To investigate potential cations or anions in the strip solution requires development of ${ }^{137} \mathrm{Cs}$ removal methods that do not interfere with the analyte. 


\subsection{CONCLUSIONS}

Researchers demonstrated the CSSX process flow sheet for the decontamination high-level dissolved salt cake waste using a 33-stage, 2-cm centrifugal contactor apparatus at the Savannah River Technology Center. Two tests, lasting 4 hours and 25.5 hours, processed simulated Tank $37 \mathrm{H}$ waste and actual Tank $37 \mathrm{H}$ waste, respectively. Test results support the following conclusions.

Hydraulic Performance: Contactors using dissolved salt cake waste and modified solvent provide excellent hydraulic performance. In both the spiked simulant test and actual waste demonstration, the system operated uninterrupted for the entire duration of the test campaign.

Solvent Retention: Carryover of organic solvent in aqueous streams (and aqueous in organic streams) was much less than $1 \%$ when processing Tank $37 \mathrm{H}$ waste. Any differences in the composition of the Tank $37 \mathrm{H}$ dissolved salt cake solution, relative to supernate solution, did not affect the ability of the contactors to efficiently separate the organic and aqueous phases. Analysis of process streams indicates minor amounts of entrainment occurs.

Waste Decontamination: The CSSX process is capable of reducing the concentration of ${ }^{137} \mathrm{Cs}$ in Tank $37 \mathrm{H}$ waste to below the Saltstone waste acceptance criterion of $45 \mathrm{nCi} / \mathrm{g}$. The Tank $37 \mathrm{H}$ waste required a DF of 25,800 to meet the Saltstone WAC. During this test 44.6 L of Tank $37 \mathrm{H}$ waste solution were processed, and the composite met the Saltstone WAC. The process achieved DFs as high as 3.3 million. The DF values averaged 352,000 during the first 16 hours of operation (at nominal solvent flow conditions) and 28,600 during the remaining 9.5 hours (at reduced solvent flow conditions).

Cesium Concentration: The process produced average CFs of 13.2 and 15.8 using Tank $37 \mathrm{H}$ waste solution. The former average was obtained in the first 16 hours of operation (at nominal solvent flow conditions), and the latter average was obtained in the final 9.5 hours of operation (at reduced solvent flow conditions). The CF value of 13.2 for the first part of the test is approximately $12 \%$ less than the target $\mathrm{CF}$ value of 15 . However, the reduced cesium concentration performance likely results from uncertainties in process flow control rather than from process chemistry limitations. 


\subsection{FUTURE WORK}

We recommend further work with dissolved salt cake waste. Although the current test provides initial indication that salt cake can be successfully processed by the CSSX process, the data base has limitations. First, performance of the strip section was adequate but borderline with this waste. Although this may be the result of the selected flow rates or an artifact of the small scale equipment, additional data is required to provide a stronger basis for large-scale operations. Second, the Tank $37 \mathrm{H}$ waste used in this test differed little from supernate waste. Further testing with waste containing low hydroxide $(<3 \mathrm{M})$ and cesium, and high nitrate and nitrite is recommended.

It is recommended that future work for the CSSX process focus more upon scrub and strip section performance. This current work and previous demonstrations show that the performance of the extraction section is fairly well understood. However, the data indicate that improvements can be made in managing scrub and strip section performance. The current study demonstrates that strip section performance is strongly dependent upon solvent and strip flow rates with limited tolerance for variations.

The data from the current study also demonstrate that the process can be operated at reduced solvent flow, while still achieving the process goals for waste decontamination and cesium concentration. Therefore, it is recommended that future work be performed to determine the conditions at which the process flows are optimized. That is, determine the conditions of maximum waste feed and minimum solvent feed at which process goals are still achieved. Optimization of the process will permit the maintenance of a minimum working solvent inventory, thus reducing material costs.

Finally it is recommended that the 2-cm centrifugal contactor apparatus be overhauled prior to any future testing. Deployment of the test apparatus in the shielded facility for three test campaigns over a sixteen month period resulted in significant wear on many components. Prior to further testing, flow measurement and control instrumentation should be modified or replaced on the 2-cm contactor apparatus to improve flow accuracy during operations. The test apparatus needs thorough cleaning. Electronic instrumentation, pumps, tubing and fittings should be inspected and replaced where needed. 


\subsection{ACKNOWLEDGEMENTS}

The authors thankfully acknowledge the helpful discussions and leadership provided by Major C. Thompson of SRTC who is the Tank Focus Area System Lead for the CSSX process. In addition, we thank Lucy Beasley, Jane Howard, Maurice Lee, and Nan Stanley for their dedication and support in operating the test apparatus within the shielded facility. Carolyn Conley, Ron Blessing, and Gary Hall provided additional shielded facility support. Shirley McCollum, Betty Croy, and Mona Blume provided support outside of the shielded facility. Cecilia DiPrete, David DiPrete and Teresa Eddy of ADS provided the radionuclide counting support, in many cases with very short turnaround times. Thomas White and Steve Crump helped plan and then performed the organic component analyses. L. H. Delmau of ORNL provided the enthalpy values needed for $\mathrm{D}_{\mathrm{Cs}}$ temperature corrections. 


\subsection{REFERENCES}

1. S. G. Campbell, M. W. Geeting, C. W. Kennell, J. D. Law, R. A. Leonard, M. A. Norato, R. A. Pierce, T. A. Todd, D. D. Walker, and W. R. Wilmarth, "Demonstration of CausticSide Solvent Extraction with Savannah River Site High Level Waste," WSRC-TR-200100223, Revision 0, April 19, 2001.

2. M. A. Norato, S. G. Campbell, M. L. Crowder, M. W. Geeting, G. F. Kessinger, R. A. Pierce, and D. D. Walker, "High Level Waste Demonstration of the Caustic-Side Solvent Extraction Process with Optimized Solvent in the 2-cm Centrifugal Contactor Apparatus," WSRC-TR-2002-00243, August, 2002.

3. Bonnesen, Peter V., et al., Alkaline-Side Extraction of Cesium from Savannah River Tank Waste Using a Calixarene-Crown Ether Extractant, ORNL/TM-13704, 1998.

4. Delmau, Laetitia H., et al., Improved Performance of the Alkaline-Side CSEX Process for Cesium Extraction from Alkaline High-Level Waste Obtained by Characterization of the Effect of Surfactant Impurities, ORNL/TM-1999/209, 1999.

5. L. H. Delmau, T. J. Haverlock, and B. A. Moyer, "Caustic-Side Solvent Extraction: AntiCaking Surfactants Found to Be Cause of Apparent Effect of High Nitrite Concentration on Cesium Stripping," ORNL/TM-2002/104, May 2002.

6. Q. L. Nguyen and J. C. Mark, "Tank 37 Salt Removal Operating Plan," U-ESR-H-00039, Rev. 2, June 26, 2002.

7. M. A. Norato, "Task Technical and Quality Assurance Plan for Solvent Extraction Actual Waste Testing - 2-cm Centrifugal Contactor Testing for Optimized CSSX Solvent and Dissolved Saltcake Actual Waste Feed," WSRC-RP-2001-00999, Rev. 0, December 12, 2001.

8. S. D. Fink, D. T. Hobbs, M. A. Norato, T. B. Peters, and D. D. Walker, "Demonstration of MST and Permanganate Efficiency on Removal of Actinides and Strontium from Savannah River Site High Level Waste," WSRC-TR-2002-00355, August, 2002.

9. D. D. Walker, "CSSX Contactor Operation (U)," WSRC L12.1, Procedure IWT-OP-136, Rev. 1, March 20, 2001.

10. P. V. Bonnesen, L. H. Delmau, B. A. Moyer, and R. A. Leonard, "A Robust AlkalineSide CSEX Solvent Suitable for Removing Cesium from Savannah River High Level Waste," Solvent Extraction and Ion Exchange, 18, 1079 (2000)

11. W. R. Wilmarth, D. P. Healy, D. J. Wheeler, J. T. Mills, V. H. Dukes, D. P. DiPrete, and L. H. Delmau, "CSSX Batch Measurements for SRS High Level Waste Samples and Dissolved Saltcake," WSRC-TR-2002-00336, July 19, 2002. 
12. L. H. Delmau, "Caustic-Side Solvent Extraction: Extended Equilibrium Modeling of Cesium and Potassium Distribution Behavior," ORNL/TM-2002/116, May 2002.

13. R. A. Leonard and M. C. Regalbuto, "A Spreadsheet Algorithm for Stagewise Solvent Extraction," Solvent Extraction and Ion Exchange, 12, 909 (1994).

14. R. A. Dimenna, H. H. Elder, J. R. Fowler, R. C. Fowler, M. V. Gregory, T. Hang, R. A. Jacobs, P. K. Paul, J. A. Pike, P. L. Rutland, F. G. Smith III, S. G. Subosits, G. A. Taylor, and S. G. Campbell, "Bases, Assumptions, and Results of the Flowsheet Calculations for the Decision Phase Salt Disposition Alternatives," WSRC-RP-99-00006, Rev. 1, October 9, 2000.

15. B. A. Moyer, et al., "Caustic-Side Solvent Extraction Chemical and Physical Properties Progress in FY 2000 and FY 2001," ORNL/TM-2001/285, February 2002.

16. R. A. Leonard, S. B. Aase, H. A. Arafat, C. Conner, J. R. Falkenberg, M. C. Regalbuto, and G. F. Vandegrift, "Simulant Flowsheet Test with Modified Solvent for Cesium Removal Using Caustic-Side Solvent Extraction," ANL-02/22, April 22, 2002.

17. F. M. Pennebaker, D. P. DiPrete, and M. A. Malek, "Analytical Methods for Cs- 137 and Other Radionuclides in Solvent Samples," WSRC-TR-2002-308, July 17, 2002.

18. J. D. Law and T. A. Todd, "Experimental Test Plan for TTP ID72WWT21: Centrifugal Contactor Hydraulic Performance of Optimized Solvent," INEEL/EXT-02-00105, Rev. 0, January 24, 2002.

19. R. A. Leonard, S. B. Aase, H. A. Arafat, C. Conner, J. R. Falkenberg, and G. F. Vandegrift, "Development of an Improved 2-cm Centrifugal Contactor for Cesium Removal from High-Level Waste," ANL-01/23, September 2001. 
WSRC-TR-2002-00307, REV. 0

\subsection{APPENDIX A}

\section{ANALYTICAL PLAN FOR THE CSSX CONTACTOR TEST USING OPTIMIZED SOLVENT AND ACTUAL WASTE}

\section{SUMMARY}

This memorandum describes the analytical plan for the Caustic Side Solvent Extraction (CSSX) contactor tests using optimized solvent and the remaining Tank 37H/44F composite sample and the Tank $37 \mathrm{H}$ dissolved salt sample. The plan requires taking 282 samples for 316 analyses by Analytical Development Section (ADS) during five tests.

\section{TEST OBJECTIVES AND ANALYTICAL REQUIREMENTS}

The objectives of the tests are to demonstrate the hydraulic performance and the extraction, scrub, and strip efficiencies of the optimized solvent with actual Savannah River Site (SRS) high-level radioactive waste. Five contactor test runs are planned. These are described below, highlighting the major objectives of each test and the analytical sampling and analyses required to meet the objectives. A summary is given in Table I.

\section{Test 1: Hydraulic Capacity Test with Tank 37H/44F Simulant (no Cesium)}

Test description: This test uses the 33-stage 2-cm contactor apparatus with the optimized solvent and non-radioactive simulant of the Tank 37H/44F composite waste. This simulant will contain no cold cesium to prevent cesium-contamination of the apparatus. All four process steps (extraction, scrub, strip, and wash) will be tested simultaneously. Organic and aqueous stream flows will be controlled and monitored by the computerized control and data acquisition system. Flow rates will be varied and the response of the apparatus recorded (i.e., liquid level in stages, phase appearance in decanters, and foaming).

Objective: Determine the maximum hydraulic capacity of the contactor apparatus with optimized solvent.

Sampling and Analytical requirements: No samples of process streams or chemical analyses are required during the test.

\section{Test 2: Tank 37H/44F Simulant with ${ }^{137}$ Cs Tracer Test}

Test description: This test uses the 33-stage 2-cm contactor apparatus with the optimized solvent and a ${ }^{137} \mathrm{Cs}$ spiked Tank $37 \mathrm{H} / 44 \mathrm{~F}$ simulant. All four process steps (extraction, scrub, strip, and wash) will be operated simultaneously in a 12-hour test. Organic and aqueous stream flows will be controlled and monitored by the computerized control and data acquisition system. Flow rates will be set near the maximum hydraulic capacity determined in Test \#1. The apparatus will be monitored for hydraulic stability. 
Objective 1: Measure decontamination and concentration factors in process streams.

Sampling and Analytical requirements: Three process streams (aqueous raffinate, strip effluent, and stripped solvent) will be sampled hourly during the test (12 samples for each stream, total 36 samples). These samples will be analyzed for ${ }^{137} \mathrm{Cs}$ by gamma scan. The spiked simulant solution will be sampled and analyzed for its major constituents and ${ }^{137} \mathrm{Cs}$.

Objective 2: Measure changes in solvent composition.

Sampling and Analytical Requirements: The solvent hold tank will be sampled initially and at the end of the test (2 samples). These will be analyzed for modifier and BOBCalix (by HPLC), TOA TMA, n-butanol, and TBP (by GC-MS). Metals (Al, K, and others) will be analyzed by ICP-ES directly on the solvent samples.

Objective 3: Measure entrainment of solvent in the aqueous raffinate, strip raffinate, and spent wash solutions. Measure entrainment of the strip solution in the solvent.

Sampling and Analytical Requirements: Entrainment will be determined by measuring the volume of the separated phase that accumulates in the decanters. Entrainment that passes the decanters will not be measured.

\section{Test 3: Tank 37H/44F Composite Waste Test}

Test description: This test uses the 33-stage 2-cm contactor apparatus with the optimized solvent and Tank $37 \mathrm{H} / 44 \mathrm{~F}$ composite waste. All four process steps (extraction, scrub, strip, and wash) will be operated simultaneously in a 24-hour test. Organic and aqueous stream flows will be controlled and monitored by the computerized control and data acquisition system. Flow rates will be set near the maximum hydraulic capacity determined in Tests \#1 and \#2. The apparatus will be monitored for hydraulic stability.

Objective 1: Measure decontamination and concentration factors in process streams.

Sampling and Analytical requirements: Three process streams (aqueous raffinate, strip effluent, and stripped solvent) will be sampled hourly during the test ( 24 samples for each stream, total 72 samples). These samples will be analyzed for ${ }^{137} \mathrm{Cs}$ by gamma counting. The aqueous raffinate and stripped solvent samples will contain low levels of activity and will be removed from the shielded facility for counting. The strip effluent will be highly radioactive and will be transferred to Cell Block B of the shielded facility for analysis using the in-cell counter.

Objective 2: Measure changes in solvent composition.

Sampling and Analytical Requirements: The solvent hold tank will be sampled initially, and at the end of the test (2 samples). These will be analyzed for modifier and BOBCalix (by HPLC), TOA TMA, n-butanol, and TBP (by GC-MS). Metals (Al, K, and others) will be analyzed by ICP-ES directly on the solvent samples.

Objective 3: Measure entrainment of solvent in the aqueous raffinate, strip raffinate, and spent wash solutions. Measure entrainment of the strip solution in the solvent.

Sampling and Analytical Requirements: Entrainment will be determined principally by measuring the volume of the separated phase that accumulates in the decanters. In addition, 
organic entrainment (in the three aqueous streams) that escapes the decanters will be measured by analyzing samples for solvent components and sec-butylphenol. Duplicate samples of the three aqueous streams shall be taken in preweighed glass vials after 5 and 11 , and 17 hours (18 samples). The sample vials must be weighed with sample, extracted, and the extract analyzed. Modifier and BOBCalix are analyzed by HPLC. Isopar ${ }^{\circledR} \mathrm{L}, \mathrm{TOA}$, and sec-butylphenol are analyzed by GC-MS (SVOA procedure).

Objective 4: Measure stage efficiencies.

Sampling and Analytical Requirements: At the end of the test, all 33 stages will be drained and saved. Every other stage sample will be analyzed. The hottest phases will be separated in the shielded facility and the others may be removed and separated in a radiohood. Both phases will be sent for analysis of cesium by gamma scan.

\section{Test 4: Tank 37H Dissolved Salt Simulant with ${ }^{137}$ Cs Tracer Test}

Test description: This 4-hour test serves the same purpose and will be performed as described above for Test 2 . The only exception will be the use of Tank $37 \mathrm{H}$ dissolved salt spiked simulant instead of Tank $37 \mathrm{H} / 44 \mathrm{~F}$ simulant. The objectives and analytical requirements are identical to Test 2 .

\section{Test 5: Tank 37H Dissolved Salt Actual Waste Test}

Test description: This test serves the same purpose and will be performed as described above for Test 3. The only exception will be the use of Tank $37 \mathrm{H}$ dissolved salt actual waste instead of Tank 37H/44F composite waste. The objectives and analytical requirements are identical to Test 3 .

\section{SIMULANT, SCRUB, STRIP, AND WASH SOLUTIONS}

The composition of the simulant, solvent, scrub, strip, and wash solutions must be verified before use. Physical properties (density, viscosity, and heat capacity/thermal conductivity) of the simulants, Tank 37H/44F composite waste, Tank $37 \mathrm{H}$ dissolved salt waste, solvent, scrub, strip, and wash solutions are required. Table II lists the analytical requirements for these solutions.

\section{STAGE SAMPLE HANDLING}

Stage samples will be obtained from all stages at the end of each test. However, not all of the samples will be analyzed. Samples that are not analyzed initially will be saved as backups in case the initial samples are compromised. All stage samples will be taken in polypropylene bottles.

Stage samples will be shaken in the polypropylene bottles for approximately one minute and then transferred to separatory funnels. The solutions will be allowed to separate for a minimum of 16 hours, whereupon the two phases will be separated. The intermediate portions containing aqueous and solvent will be discarded. 


\section{HIGHLY RADIOACTIVE SAMPLES}

During the radioactive waste tests (Tests 3 and 5), some samples will be too radioactive to remove from the shielded facility. The aqueous concentrate and some of the stage samples will contain ${ }^{137} \mathrm{Cs}$ in excess of $5 \times 10^{7} \mathrm{~d} / \mathrm{m} / \mathrm{mL}$ which prior experience has shown to be a practical limit for removal of a few milliliters of sample. Aqueous or organic samples requiring gamma scans will be transferred to Cell Block B and analyzed in the in-cell counter. For aqueous samples requiring organic analyses for carryover of solvent, the samples will be extracted in the shielded facility and the extract removed for analysis. 

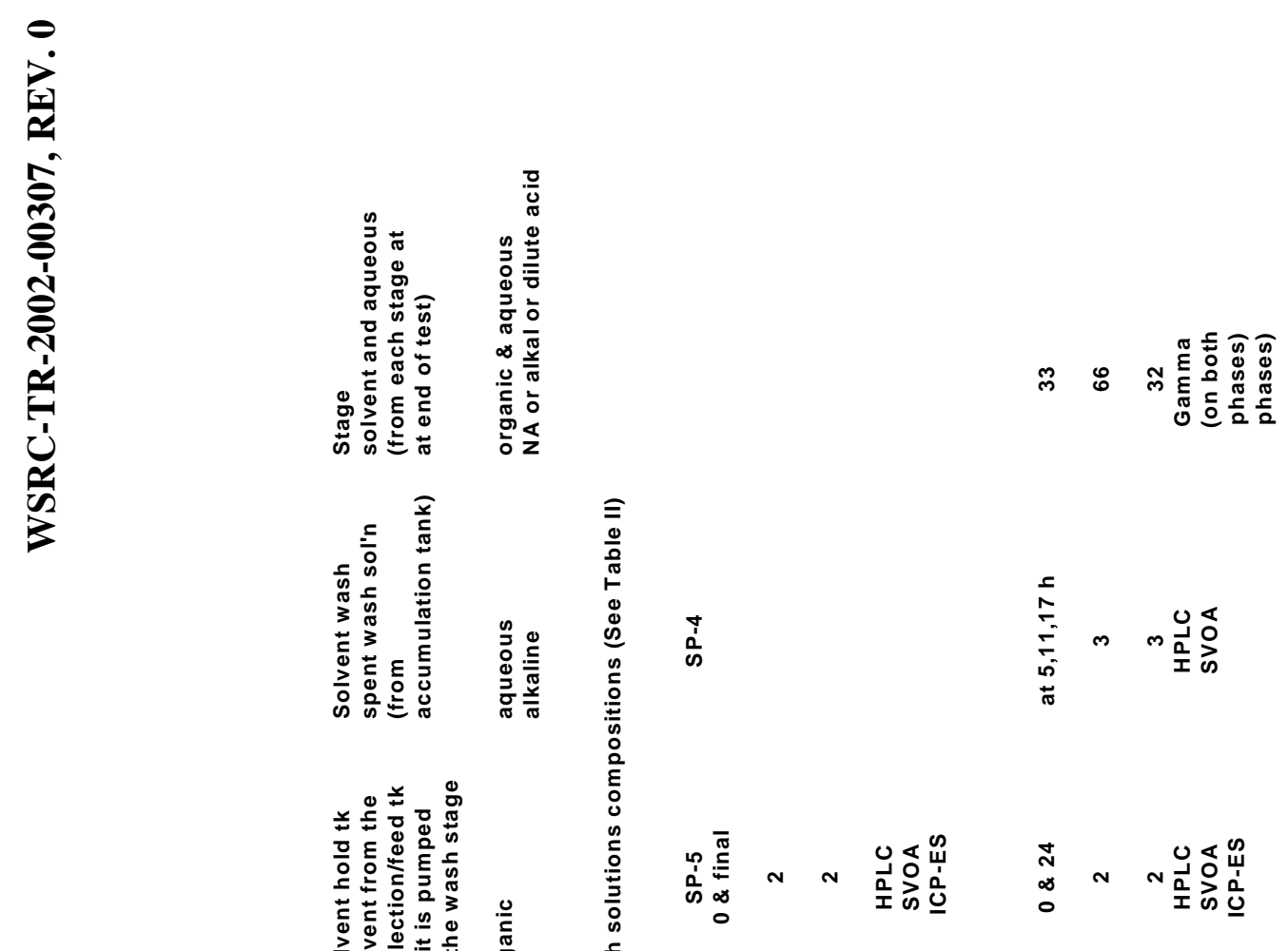

लं
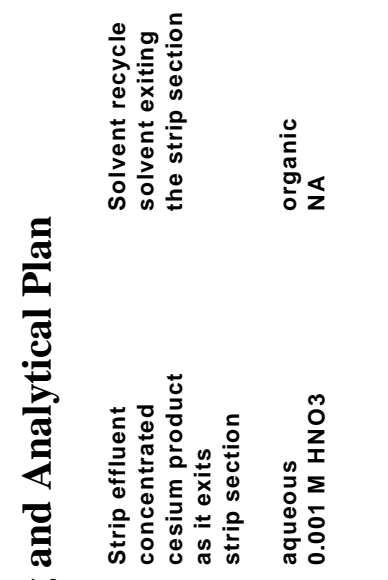

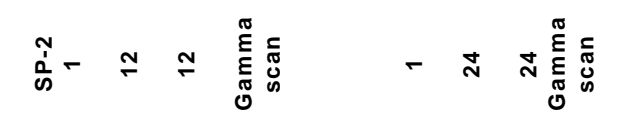

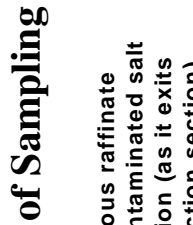

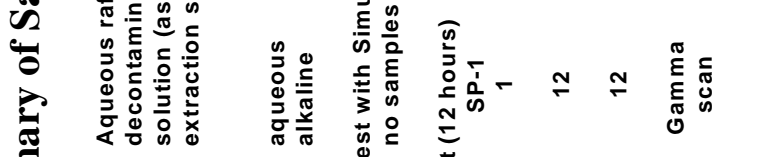
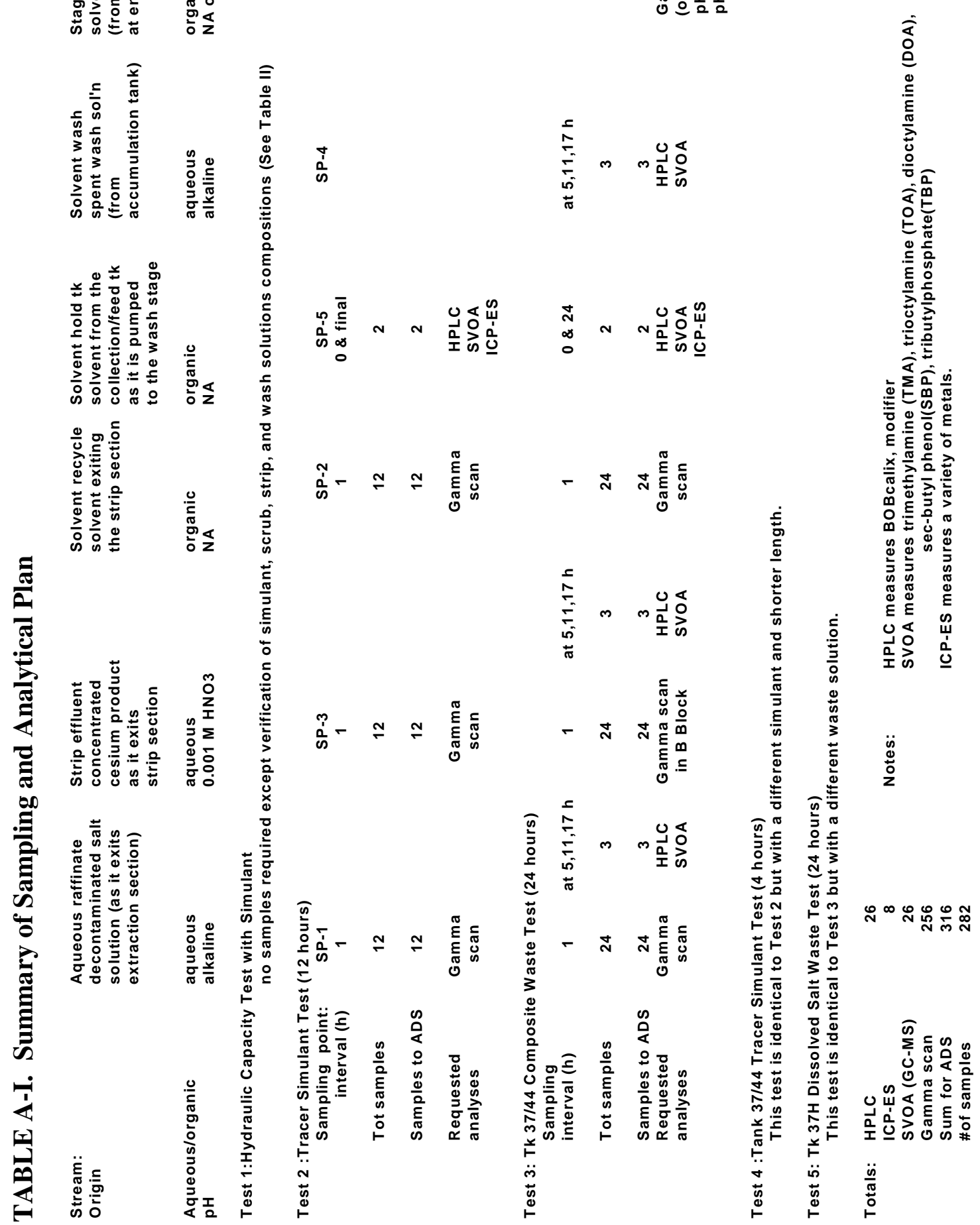
TABLE A-II. Analyses of Simulant, Scrub, Strip, and Wash Solutions.

$\underline{\text { Component }}$

$\underline{\text { Scrub }} \stackrel{\text { Solution }}{\text { Strip }} \underline{\text { Wash }}$

Total acid

$\mathrm{x}$

$\mathrm{x}$

Total $\mathrm{OH}$

$\mathrm{x}$

Free $\mathrm{OH}$

$\mathrm{X}$

Carbonate

$\mathrm{X}$

Aluminate

IC anions

$\mathrm{X}$

IC (DBP)*

$\mathrm{X}$

Cs (AA)

$\mathrm{X}$

$\mathrm{K}$ (AA)

$\mathrm{Na}(\mathrm{ICP}-\mathrm{ES})$

SVOA**

${ }^{137}$ Cs (gamma scan)

$\mathrm{X}$

$\mathrm{X}$

$\mathrm{X}$

$\mathrm{x}($ triplicate $)$

*For dibutylphosphate. $\mathrm{IC}=$ ion chromatography

** For trimethylamine and tributylphosphate. SVOA = semivolatile organic analysis. 